\title{
A systematic review and meta-analysis of unplanned hospital visits and re-admissions following radical prostatectomy for prostate cancer
}

Avinash N. Mukkala ${ }^{1,2}$; Jasmine B. Song, $\mathrm{MPH}^{3}$; Michelle Lee ${ }^{4}$; Alexandra Boasie, MSc, $\mathrm{MBA}^{5}$; Jonathan Irish, MD, MSc, FRCSC, FACS ${ }^{6,7}$; Antonio Finelli, MD, FRCSC ${ }^{8,9}$; Alice C. Wei, MDCM, MSc, FRCSC, FACS $6,10,11$

${ }^{1}$ Institute of Medical Science, Faculty of Medicine, University of Toronto, Toronto, ON, Canada; ${ }^{2}$ Keenan Research Centre for Biomedical Science, St. Michael's Hospital, Unity Health Toronto, Toronto, ON, Canada; ${ }^{3}$ Dalla Lana School of Public Health, University of Toronto, Toronto, ON, Canada; ${ }^{4}$ Regional Cancer Program, Princess Margaret Cancer Centre, University Health Network, Toronto, ON, Canada; ${ }^{5}$ Surgery and Critical Care Program, University Health Network, Toronto, ON, Canada; ${ }^{6}$ Surgical Oncology Program, Cancer Care Ontario, Toronto, ON, Canada; ${ }^{7}$ Department of Otolaryngology-Head and Neck Surgery/Surgical Oncology, Princess Margaret Cancer Centre, University Health Network, Toronto, ON, Canada; ${ }^{8}$ Division of Urology, Department of Surgery, Princess Margaret Cancer Centre, University Health Network, Toronto, ON, Canada; ${ }^{9}$ Division of Urology, Department of Surgery, University of Toronto, Toronto, ON, Canada; ${ }^{10}$ Weill-Cornell School of Medicine, Cornell University, New York, NY, United States; ${ }^{11}$ Sloan Kettering Cancer Center, New York, NY, United States

Acknowledgements: The authors would like to thank the Surgical Oncology Program at Cancer Care Ontario.

Cite as: Mukkala AN, Song JB, Lee M, et al. A systematic review and meta-analysis of unplanned hospital visits and re-admissions following radical prostatectomy for prostate cancer. Can Urol Assoc J 2021 March 18; Epub ahead of print. http://dx.doi.org/10.5489/cuaj.6931

Published online March 18, 2021

$* * *$

\section{Abstract}

Introduction: Unplanned visits (UPV) — re-admissions and emergency room (ER) visits — are markers of healthcare system quality. Radical prostatectomy (RP) is a commonly performed cancer procedure, where variation in UPV represents a gap in care for prostate cancer patients. Here, we systematically synthesize the rates, reasons, predictors, and interventions for UPV after $\mathrm{RP}$, to inform evidence-based quality improvement (QI) initiatives.

Methods: A systematic review was performed for studies from 2000-2020 using keywords: "readmission," "emergency room/department," "unplanned visit," and "prostatectomy." Studies that focused on UPV following RP and that reported rates, reasons, predictors, or interventions, were included. Data was extracted via a standardized form. Meta-analysis was completed. 
Results: Sixty studies, with 406107 RP patients, were eligible; 16028 UPV events ( 5\%) were analyzed from 317050 RP patients. UPV rates after RP varied between studies (ER visit range 6-24\%; re-admissions range $0-56 \%$ ). The 30-day and 90-day ER visit rates were 12\% and 14\%, respectively; the 30-day and 90-day re-admission rates were 4\% and 9\%, respectively. A total of $55 \%$ of all re-admissions after RP are directly due to postoperative genitourinary (GU)-related complications such as strictures, obstructions, fistula, bladder-related, incontinence, urine leak, renal problems, and other unspecified urinary complications. The next most common readmission reasons were anastomosis-related, infection-related, cardiovascular/pulmonary events, and wound-related issues. Thirty-four percent of all ER visits after RP are directly due to urinerelated issues such as retention, urinoma, obstruction, leak, and catheter problems. The next most common ER visit reasons were abdominal/gastrointestinal issues, infection-related, venous thromboembolic events, and wound-related issues. Predictors for increased re-admission included: open RP, lymph node dissection, Charlson comorbidity index $\geq 2$, low surgeon/hospital case volume, and socioeconomic determinants of health. Of the 10 interventions evaluated, a $3.4 \%$ average reduction in UPV rate was observed, highlighting an approximate two-fold decrease. Meta-analysis demonstrated a significant benefit of interventions over controls with odds ratio 0.62 (95\% confidence interval $0.46-0.84)$. Interventions that used multidisciplinary, nurse-centered, programs, with patient self-care/empowerment were more beneficial than algorithmic patient care pathways and preoperative patient education.

Conclusions: Twenty years of international, retrospective, experience suggests UPV after RP are often related to GU complications, infection- or wound-related factors. QI interventions to reduce UPV should target these factors. While many re-admissions after RP appear to be unavoidable, ER visits have more opportunity for volume reduction by QI. The interventions evaluated herein have potential to reduce UPV after RP.

\section{Introduction}

Prostate cancer (PC) is the second most common cancer, with $>1.28 \mathrm{M}$ new cases per year. ${ }^{1}$ PC has international variation in incidence and mortality rates dependent on income and resource status of countries. ${ }^{2}$ The most common treatment for localized PC is radical prostatectomy (RP). Approximately nine thousand RPs are performed every year in Canada, and ninety thousand in the USA. ${ }^{3,4}$ Although the five-year survival rate of $\mathrm{PC}$ is $98 \%$, morbidity remains important for quality-of-care improvements.

Unplanned visits (UPV) after index hospitalization - including re-admissions and emergency room (ER) visits - are quality of care indicators. ${ }^{5-10}$ Reducing re-admissions and ER visits is a policy priority. ${ }^{9}$ In California, the California Cancer Registry reports that $14.7 \%$ of PC 
patients experience unplanned hospitalizations after index admission. ${ }^{11}$ In Ontario, Cancer Care Ontario has reported that $28 \%$ of PC-RP patients have UPV (3.2\% re-admission and $24.7 \%$ ER visits), hence contributing to increased healthcare costs and suboptimal patient outcomes. ${ }^{9}$ Patients who undergo RP for PC have the highest rate of ER visits compared to breast, lung and colorectal cancer patients. ${ }^{9}$ The intricate causality of re-admissions leads to disagreement about whether re-admissions can be averted, while many studies have shown a connection between successful QI initiatives and reductions in re-admission. ${ }^{10}$ Although re-admission rates are a promising quality indicator, data suggests that they alone do not reflect quality of care, and hence policy makers should consider augmenting their use with other measures of hospital quality. ${ }^{12-15}$

Reducing UPVs is dependent on multiple factors, such as medical avoidability, cancer site, and procedure type. In all types of patients, a systematic review of 34 studies reported that the proportion of avoidable re-admission varies, with a median of $27.1 \%$, and a wide range from $5 \%$ to $79 \% .{ }^{16}$ In a cohort of general medicine patients, Auerbach et al. found that $26.9 \%$ of readmissions may be avoidable. ${ }^{17}$ Comprehensive understanding of the rates, reasons, and predictors of UPV is important for developing effective quality improvement (QI) interventions.

UPV after surgery are morbid for the patients and increase costs for the system, therefore UPV are either avoidable or necessary in healthcare. In this study, we performed a systematic review and meta-analysis to evaluate UPVs following RP. We report the rates, reasons, predictors for UPV, and appraise the interventions used to reduce UPV.

\section{Methods}

Preferred Reporting Items for Systematic Reviews and Meta-analyses (PRISMA) Statement was used. $^{18}$

\section{Literature search and information sources}

MEDLINE (OVID), PubMed (NCBI) and EMBASE (OVID) were searched from January 2000 to December 2020 using a search strategy that combined the keywords "re-admission," "unplanned visit," "emergency room visit" and, "radical prostatectomy" (Supp. Table 1) (ANM). Iterative inclusion and exclusion of search terminology was used to encompass the relevant literature. A two-step deduplication process was used with EndNote (v8.0, Clarivate Analytics, Philadelphia, USA), and Systematic Review Assistant-Deduplication Module (SRA-DM) (v2.4.3, Bond University Centre for Research in Evidence-Based Practice, CREBP, Robina, Australia). ${ }^{19}$ The last search was performed in Dec 2020.

\section{Eligibility criteria and study selection}

English language studies that focused on UPV and RP were included. Outcomes of interest were re-admission or ER visit within 30- or 90-days. Exclusion criteria included: studies that did not report any outcomes of interest, purely cost analyses/economics, other prostatectomy, and molecular/basic science mechanistic/pathogenesis research. The references of systematic and 
narrative reviews were examined to identify additional studies. Conference abstracts/papers, editorials/letters, commentaries, news articles, opinion pieces, small $\mathrm{N}<50$ case series and case reports were excluded. If studies reported UPV rates, reasons for UPV, predictors of UPV, or interventions that reported any UPV outcomes, they were included (Figure 1). An initial screening of title and abstract was performed, and the full text of potentially eligible studies were reviewed (ANM and JBS) for eligibility (Figure 1).

All studies that passed title/abstract screening underwent full-text review to assess inclusion eligibility (Figure 1). Inclusion/exclusion discrepancies were solved by a third reviewer (ML). Studies that included at least one outcome/variable of interest were included (Figure 1).

\section{Data abstraction and organization}

Data abstraction was performed by two independent abstractors (ANM and JBS) using a standardized collection form. Data extracted included: study characteristics, rates, reasons, predictors, and interventions for UPV following RP. Rates of re-admission and ER visit were calculated. Reasons for re-admission and ER visit were compiled in table format. Given that an extremely low proportion of patients have an UPV event (likely $<10 \%$ ) and most reported hazard $\mathrm{s} /$ odds/risk ratios are near 1 , statistically significant $(\mathrm{p}<0.05)$ predictors of re-admission were reported as raw effect estimate ratios for later meta-analytic input. Reasons for UPV were grouped into sub-categories and presented in tabular format and summarized by incidence. Any re-admission from all studies was considered to be an UPV, implying direct admission to hospital. Any ER visit from all studies was considered an UPV.

\section{Crude meta-analysis of re-admission predictors}

Effect estimates were natural logarithm transformed and entered into Med Calc (v.19.1.1.). Generic inverse variance analysis was conducted for predictors with $>1$ reporting study (Supp. Fig. 1). ${ }^{20}$ Forest and funnel plots and meta-analytic outputs were summarized in figures. Other non-groupable predictors are illustrated as a crude forest plot.

\section{Meta-analysis of UPV interventions}

Any interventional (case-control) study that reported any UPV outcome data (primary or otherwise, all endpoints) were included in the meta-analysis. Meta-analysis was conducted using the Mantel-Haenszel method in Rev man (v.5.4.1.), using both fixed and random effects models. Heterogeneity and publication bias were approximated; forest and funnel plots were generated. Rev man tools were used to complete the risk of bias analysis. $\mathrm{P}<0.05$ was considered statistically significant in all analyses.

\section{Results}

Study characteristics (100\% reporting) 
After removal of duplicates, 998 records underwent title and abstract screening (Fig. 1). One hundred and sixteen full text studies were assessed, 60 met inclusion criteria (Fig. 1; Table 1). ${ }^{21-}$ ${ }^{80}$ Thirty-five studies were from the USA, 14 from Europe, 4 from Canada, 3 from Asia, and the rest from other continents (Table 1). ${ }^{21-80}$ The included studies were published between 2004-20 (Table 1). ${ }^{21-80}$ Thirty-four studies were from single centers, while the rest were either state/province-level, or used multi-center administrative databases (e.g. NSQIP, OHIP and SEER etc.) (Table 1). ${ }^{21-80}$ In terms of surgical approach, 50\% underwent MIRP (including 36.0\% RARP), 29\% underwent open procedures, and 21\% were unspecified RPs.

\section{Rates of UPV after RP (78\% reporting)}

The data of 406,107 patients who underwent RP is presented in table 1. All 60 studies reported an ER/ED visit and/or re-admission rate, at time frames ranging from 14-days to five-years or unknown endpoints (Table 1). ${ }^{10-60}$ A total of 16,028 ( 5\%) UPV (30- or 90-day) events were captured through our analysis of 317,050 RP patients. The 30-day and 90-day ER visit rates were $11.7 \%(463 / 3,955 ; \mathrm{n}=4$ studies $)$ and $14.0 \%(1,131 / 8,054 ; \mathrm{n}=3$ studies $)$, respectively. The 30 -day and 90 -day re-admission rates were $3.6 \%(8,520 / 238,973 ; n=28$ studies $)$ and $8.9 \%$ $(5,914 / 66,068 ; n=13$ studies $)$, respectively. Only studies that reported 30 - or 90 -day UPV rates were included in the aggregate rate analysis, and as a result 89,057 ( 22\%) RPs were excluded.

\section{Reasons for UPV after $R P$ (28\% reporting)}

Only $\sim 28 \%$ of total RP patients reported specific reasons/causes of UPV (N=113,017 patients; $\mathrm{N}=24$ studies; Table 2). All studies reported on re-admissions, and four studies reported on ER visits (Table 2). 55\% of all re-admissions after RP are directly due to post-operative complications related to GU such as strictures, obstructions, fistula, bladder-related, renal problems, and other unspecified urinary complications $(8,187 / 93,515,8.8 \%)$. The next most common reasons for re-admission, in decreasing incidence, anastomosis-related (stricture, leak, sclerosis; 1,593/21,728, 7.3\%), infection-related (abscess, UTI, epididymitis, cellulitis, orchitis, sepsis; 1,247/61,524, 2.0\%), cardiovascular/pulmonary events $(1,243 / 52,778,2.4 \%)$, and woundrelated issues (dehiscence, disruption, infection; 1,048/26,952, 3.9\%) (Table 2). 34\% of all ER visits after RP are directly due to urine-related issues such as retention, urinoma, obstruction, leak, and catheter problems $(291 / 6,563,4.4 \%)$. The next common reasons for ER visits are, in decreasing incidence, abdominal/GI issues (abdominal pain, ileus, hernia, constipation, jaundice, lymphoceles, unspecified GI issues; 157/6,563, 2.4\%), infection-related (abscess, UTI, epididymitis, cellulitis, orchitis, sepsis; 155/6,563, 2.4\%), venous thromboembolic events (VTE; 131/5,595, 2.3\%), and wound-related (dehiscence, disruption, infection; 68/6,563, 1.0\%) (Table 2). Many re-admissions appear to be medically unavoidable, while ER visits have more opportunity for volume reduction by QI. Here we highlight key groups of complaints, issues, and complications which have potential for QI targeting. 


\section{Predictors of UPV after $R P$ (56\% reporting)}

Twelve of 60 studies reported predictors of re-admission after RP (N=229,399 [56\%] patients; Supp. Fig 1; Supp. Table 2), and $98 \%$ of these patients are reported from national cancer/administrative databases. Statistically significant $(\mathrm{p}<0.05)$ predictors of re-admission after RP included: pre/post-op patient demographics and comorbidities, social/economic features, hospital or surgeon case volume, and surgical approach (Supp. Fig 1; Supp. Table 2).

Most studies have found that minimally invasive radical prostatectomy (MIRP), most commonly robot-assisted RP (RARP), predict lower odds of re-admission over open RP (ORP) (Supp. Table 2). However, in aggregate analysis of effect estimates, it was found that RARP has a non-significant positive effect on re-admission, with low study heterogeneity but high publication bias (Supp. Fig. 1a-b). Furthermore, $\mathrm{ASA} \geq 3$ has a non-significant negative effect on re-admission, with low study heterogeneity but high publication bias (Supp. Fig, 1c-d). Finally, $\mathrm{CCI} \geq 2$ (i.e., presence of comorbidities) has a significant negative effect on re-admission with low study heterogeneity but high publication bias (Supp. Fig, 1e-f).

Socioeconomic determinants of health (SDH), such as race and economic deprivation, have a significant negative effect on re-admission and ER visit, ${ }^{66,67,80}$ with low study heterogeneity but high publication bias (Supp. Fig. 1g-h). Likewise, lymph node dissection (LND) has a significant negative effect on re-admission, with low study heterogeneity but high publication bias (Supp. Fig. 1i-j). Whereas adverse markers of tumor pathology (such as AJCC T3, Gleason score $>8$ etc.) have a significant negative effect on re-admission, but this result is attributed with high study heterogeneity and high publication bias.

A large variety of pre/post-operative patient characteristics have been associated with significantly increased odds of re-admission (Supp. Table 2; Supp. Fig. 1m). Preoperative factors associated with increased re-admission included: mental disorders, cardiopulmonary diseases, older age, and high BMI $>35$ (Supp. Table 2; Supp. Fig. 1m). On the other hand, high surgeon $(>18 / y)$ or hospital case volume $(\geq 46 / y, \geq 150 / y)$, through a minimally invasive approach, have been associated with significantly decreased odds of re-admission (Supp. Table 2; Supp. Fig. $1 \mathrm{~m})$. Other factors that predict higher re-admission include: age $>70 \mathrm{y}, \operatorname{LoS}>3 \mathrm{~d}$, high operative time $>251 \mathrm{mins}$, and the presence of post-operative complications (Supp. Table 2; Supp. Fig. $1 \mathrm{~m})$.

In this crude meta-analysis of effect estimates, publication bias was high, and hence these predictors should also be interpreted individually (Supp. Table 2), and within healthcare system contexts, when formulating QI initiatives to reduce UPV. For example, using these predictors as risk stratification indicators can help focus clinical attention on those patients that are at the most risk of UPV, hence potentially improving healthcare quality.

Interventions that reduce UPV after RP: meta-analysis and narrative summary (1\% reporting) 4,154 ( 1\%) RP patients were included in the interventions analysis. A 3.4\% average reduction in UPV rate is achievable as an effect of the ten evaluated interventions, highlighting a $\sim$-fold 
average decrease in UPV rate (intervention UPV rate $=4.85 \%$; control UPV rate $=9.45 \%$ ) (Fig. 2c-d). Tested interventions significantly lowered UPV rate as compared to paired control groups per study (Mean of differences=3.39\% [95\% CI: 0.01-6.69\%], $\mathrm{p}=0.0455$, pairing effectiveness, $\mathrm{p}<0.0001$ ) (Fig. 2c-d).

Meta-analysis of these ten studies showed an overall effect estimate of 0.62 [95\% CI: 0.46-0.84] (FE: $p=0.002$; RE: $p=0.008$ ), favoring interventions over controls (Fig. 3a). There was no detection of heterogeneity $\left(\mathrm{Q}=7.3017, \mathrm{p}=0.6057 ; \mathrm{I}^{2}=0.00 \%[0-53.86 \%]\right)$ or publication bias (Egger's $p=0.6315$; Begg's $p=0.4208$ ) (Fig. 2a-b). The overall low quality of the included studies resulted in a high risk of bias (Fig. 2a). Re-admission or ER visit are reported as only secondary outcomes in these studies, and therefore more studies that focus primary outcomes on UPV are needed to draw more precise conclusions.

Ten of 60 studies tested interventions, ${ }^{21-23,29,32,37,42,45,51,76}$ such as standardized care pathways, ERAS and fast-track surgery (FTS), and medical/surgical alterations of clinical course (Table 3). Care pathway-like standardized nursing plans and patient education programs did demonstrate only a slight reduction in re-admission and ER visit (Table 3). ${ }^{21}$ Likewise, home health care services increased ER visit at 16-days ( $p<0.01$ ), but appeared to be effective for lowering re-admission ( $\mathrm{p}=0.06$ ) (Table 3$).{ }^{37}$ In a short-stay ambulatory extended recovery program aimed at reducing length of stay, drain management lessons, web-based interactive classes, and printed materials did not change re-admission and ER visit after RP (Table 3). ${ }^{51}$

However, other support systems with ready-access to healthcare personnel are shown to be more effective. ${ }^{23,29,76}$ In Australia, Birch et al. have demonstrated that a 10-step nurse-led "Robocare" pathway for RARP is effective at reducing re-admission (no statistics reported; Table 3). ${ }^{23}$ A specialist nurse that is closely involved with patient care at every step, with a longterm follow-up phone clinic, and pre/post-operative education were shown to be effective components of "Robocare" (Table 4), in terms of patient satisfaction surveys. ${ }^{23}$ Similarly, a pilot study from Canada by Flannigan et al. demonstrated significantly lowered UPV (131/321 vs. 20/115, $\mathrm{p}=0.02$ ), using a nurse-centered standardized follow-up program which focused on catheter-, staple- and drain-related management issues (Table 4). ${ }^{29}$ Another key element in this study was that RP patients had telephone access to the nurse for inquiries, who was able to quickly solve minor issues without a need for UPV (Table 4). ${ }^{29}$

A standardized care pathway, from Turini et al., illustrated that a $75 \%$ re-admission reduction (with no significant changes in ER visit) is possible using their component methodologies, with excellent patient satisfaction levels (Table 3). ${ }^{76}$ Some of the components of their pathway included: explicit preoperative instruction, preoperative pelvic floor rehabilitation, intraoperative opium suppository, postoperative MIRP coordinator visit to answer questions without delay, complete Foley catheter instructions, stool softener, and follow-up phone call. ${ }^{76} \mathrm{~A}$ fast-track surgery (FTS) program in LRP found no effect on re-admission. ${ }^{32}$ Finally, Lin and 
colleagues report that an ERAS program after LRP has significant benefits for short-term outcomes, while having no effect on re-admission rates. ${ }^{45}$

\section{Discussion}

In this comprehensive systematic review and meta-analysis, we found that the UPV visit rate was $3.6 \%$ for re-admission and $11.7 \%$ for ER visit at 30 days after RP. 55\% of all re-admissions after $\mathrm{RP}$ are directly due to post-operative complications related to GU such as strictures, obstructions, fistula, bladder-related, renal problems, and other unspecified urinary complications. $34 \%$ of all ER visits after RP are directly due to urine-related issues such as retention, urinoma, obstruction, leak, and catheter problems. Other common reasons for UPV are infection-related (abscess, UTI, epididymitis, cellulitis, orchitis, sepsis) and wound-related issues (dehiscence, disruption, infection). Intervention studies performed to reduce UPV included: care pathways, ERAS/FTS, discharge planning nursing interventions, medical/surgical interventions, and patient education, among others. All things considered, a multidisciplinary, nurse-centered, intervention seems most likely to be effective at reducing UPV after RP to improve outcomes.

Patients return to hospital due to urinary catheter, wound- or drain-related reasons (Table 2). This study reports the most common reasons and hence helps shed light onto the questions around UPV preventability. Of note there are several risk factors for re-admission including lower socioeconomic status, black race, low surgeon, and hospital case volume (Supp. Table 2; Supp. Fig. 1). Consistently, studies found that robotic RP is associated with lower odds of readmission (Supp. Table 2). Although, regional and national healthcare system infrastructure does not support RARP in many parts of the world. It has been suggested that using these factors for prospective stratification of high-risk patients can aid in tailoring length of stay and targeting QI interventions. ${ }^{81-83}$ No single intervention alone is able to significantly reduce UPV rate (except Flannigan et al. and Turini et al.), ${ }^{29,76}$ however their collective effect has potential for greater significance (Table 3; Fig. 2). Our meta-analysis suggests that intervention groups are better than control groups, in terms of UPV rate, by average $\sim 2$-fold. Importantly, nurse-centered, patient education programs that promote self-care while allowing healthcare staff access are proven to be more effective at reducing re-admission and ER visit after RP, rather than information-heavy, algorithmic care pathways aimed at early discharge (Table 3). Furthermore, Ploussard et al. illustrate that ERAS and prehabilitation pathways, in synergy, can result in improved short-term surgical outcomes and reduced costs after RARP, without an increase in re-admission rate. ${ }^{62}$ The consideration of longer time-scales of medical attention (i.e., extended follow-up and preoperative prehabilitation) should not be excluded in designing QI initiatives, and hence the primacy of one dedicated staff responsible for addressing minor complications before patients require re-admission is central.

Despite the widespread efficacy of ERAS/FTS programs after RP for PC, the programs usually have positive effects on short-term post-op outcomes, such as shorter 
flatulating/defecation time, shorter time to drain removal, while having no effect on re-admission rate or blood loss. ${ }^{84,85}$ A meta-analysis from Lv et al. showed that ERAS/FTS had a nonsignificant effect on the re-admission rate outcome, hence favoring conventional care ${ }^{84}$ Further tailoring and extension of ERAS/FTS programs, using the synthesis herein, can potentially help for longer-term outcomes, such as UPV. Given that the presence of multiple complications and a short length of stay are associated with postoperative re-admissions, ${ }^{82}$ and that home health care increases ER visit rate, ${ }^{37}$ there is legible value in interventions that focus on specific groups of re-admission reasons, such as catheter problems, DVT and bleeding such as those by Afzal et al. and Kubota et al. ${ }^{22,42}$ Given that LND during RP can increase the rates of DVT/PE events, ${ }^{77}$ particular attention is warranted in this subset of RP patients. Older and more comorbid patients have higher risk of major complications after RP; our study finds that GU complications make up the majority of re-admissions, and thus preoperative assessment strategies are crucial. ${ }^{86}$ In this manner, the exact timing of post-RP complications becomes valuable knowledge. ${ }^{87}$ Merhe et al. report the timing of surgical complications after RP, and note that they occur in this approximate order: bleeding/transfusion on the same day, pneumonia and renal complications at 4 days, cardiac arrest at 5 days, DVT at 11 days, and sepsis at 12 days. ${ }^{87}$ Minor complications, such as UTIs (15d) and wound infections (16d) occur later. ${ }^{87}$ Given that $55 \%$ of all re-admissions and $36 \%$ of all ER visits are due to GU-related complications/issues, and that $46 \%$ of complications occur after index discharge, ${ }^{87}$ and that post-discharge complications are predictive of readmission (OR 16.40, $\mathrm{P}<0.001$ ), ${ }^{87} \mathrm{QI}$ initiatives should focus on post-discharge (rather than pre-discharge) interventions. Finally, during a global pandemic (COVID-19), healthcare systems are highly strained, and access to care can be lowered; hence, overnight stays or same-day discharge for RARP (and other MIRP) are considered to be safe. ${ }^{40,50,54}$

Other systematic reviews have addressed the effectiveness of interventions at reducing UPV in other disease sites and procedures. ${ }^{88-90}$ A descriptive systematic review of 43 studies, reporting 30-day UPV reduction, by Hansen et al., ultimately found that no single intervention applied in isolation was correlated with a significant drop in 30-day UPV risk (similar to our findings). ${ }^{89}$ However, Hansen et al. constructed an accurate taxonomy for the types of interventions for UPV: pre-discharge, post-discharge and bridging interventions. ${ }^{89}$ Applying a similar taxonomy, Leppin et al. performed a meta-analysis of 42 trials that tested initiatives preventing re-admission and found an overall reduced relative risk of 0.82 [95\% CI: 0.73-0.91, $\left.\mathrm{p}<0.001, \mathrm{I}^{2}=31 \%\right] .{ }^{90}$ Interestingly, pre-2002 studies were $1.6 \mathrm{x}$ more effective at reducing readmission than those published later $(\mathrm{p}=0.01) .{ }^{90}$ Interventions with multiple complex components [1.4x, $\mathrm{p}=0.001]$, with more healthcare personnel involved in management [1.3x, $\mathrm{p}=0.05]$, and facilitating patient self-care [1.3x, $\mathrm{p}=0.04]$ were significantly more effective than others. ${ }^{90}$ More recently, a comprehensive meta-analysis of 47 studies by Braet et al. found an overall relative risk reduction for re-admission [RR: 0.77 (95\% CI: 0.70-0.84), p $<0.00001$, $\mathrm{I}^{2}=34 \%$ ], ER visit [RR: 0.75 (95\% CI: 0.55-1.01), $\mathrm{p}=0.06$ ] and even mortality [RR: 0.70 (95\% 
CI: $0.48-1.01), p=0.06] .{ }^{88}$ Interventions beginning during the index hospitalization and continuing post-discharge were much more effective $(\mathrm{p}=0.01)$, yet contrary to Leppin et al., interventions with multiple components were no more effective than simpler single component interventions $(\mathrm{p}=0.54) .{ }^{88,90}$

A study by Gani et al. aimed to quantify 30-day re-admission variability that could be ascribed to patient-, surgeon- and specialty-level factors in order to elucidate patterns of possible preventability. ${ }^{91}$ A marginal proportion of the variability in re-admission was due to surgeon$(2.8 \%)$ and specialty-level (14.5\%) factors, whereas the vast majority was due to patient-related factors $(82.8 \%) .{ }^{91}$ Despite the importance of natural disease pathology, prognosis and procedure, social factors are important. As a result, developing strategies to reduce UPV may need to address the social factors that contribute to UPV (Supp. Table 2; Supp. Fig 1). Other factors such as post-operative complications, pre-operative comorbidities, ASA class and length of stay are also important (Supp. Table 2; Supp. Fig 1). ${ }^{81-83}$ Whereas socioeconomic, volume and surgical approach factors can help stratify patients before index surgery, pre-op and post-op characteristics can aid in tailoring clinical courses towards ideal in-hospital stays.

Similar to our findings, interventions focusing on patient self-care were more effective than any others $(\mathrm{p}=0.02) .{ }^{88}$ Our data suggests comparable findings to these previous systematic reviews. Studies focusing on patient empowerment, self-care facilitation, starting interventions early, tailoring the post-operative course per patient complexity, nurse-centered, and access to immediate troubleshooting via telephone were effective at reducing re-admission (Table 3). Minor complications (e.g., abdominal/GI issues, infection-related, VTE events) seem to be more likely ER visits, whereas major complications (e.g., GU-related complications, anastomosisrelated, cardiovascular/pulmonary events) are more likely to result in re-admission (Table 2); therefore, a QI initiative applies mainly to more minor issues. It must also be noted that some readmissions and ER visits are unavoidable and inevitable, but through the data herein, clinicians may gain a comprehensive picture to consider QI.

Our study has its limitations, stemming mainly from the fact that no RCTs were included, because no RCTs were available. Not all our included studies reported data for all our variables/outcomes of interest, which limited the quantitative depth of our examination. Furthermore, our study aims to serve as a guideline for clinicians planning post-surgical courses to improve quality of patient care, and therefore it is important not to overstate our findings past their collected context: RP for PC. Next, our meta-analysis also has some missing data, that is explained in Figure 2. Additionally, there were some methodological differences between the included studies that limited our full comprehension of the literature, although our narrative summaries help compensate. Furthermore, there is uncontrollable overlap and potential doublecounting of RP patients given that many of the included studies utilized national databases. Finally, our meta-analysis should be interpreted with a grain of salt considering the variability of 
UPV endpoints and high risk of bias. Further RCTs are required to help establish whether or not the interventional recommendations noted herein are valid in the overall RP patient population.

Some potential clinically-relevant strategies may include diversion from the ER and earlier re-admission of major issues; whereas minor wound infections should likely not come to the ER. Drain-, wound-, catheter-management has potential to also help reduce UPV after RP. Targeting minor post-discharge complications, while focusing on 30-day re-admission outcomes, with a comprehensive QI initiative, has potential to tackle UPVs. Evidence from our systematic review illustrates the importance of focusing clinical questions to specific disease sites and interventions, especially when assessing QI initiatives to bring about large-scale surgical quality changes in the healthcare system. Our study shows that there are some unavoidable UPVs, and different strategies can be used for different types of issues. Reducing re-admission and ER visit rates after RP can improve quality of care. Our study reports the UPV visit rates following RP and identifies the most common reasons for UPV after RP. Furthermore, we report potential stratification parameters and the efficacy of published interventions in this patient population. An understanding of the patients at risk for UPV and reasons for UPV can help inform the development of novel intervention strategies to tackle this healthcare burden. 


\section{References}

1. Rawla P. Epidemiology of Prostate Cancer. World journal of oncology. 2019;10(2):6389.

2. Center MM, Jemal A, Lortet-Tieulent $\mathrm{J}$, et al. International Variation in Prostate Cancer Incidence and Mortality Rates. European Urology. 2012;61(6):1079-1092.

3. With CIfHITDoRPtTM, Prostate Cancer. Ottawa OC.

4. Lowrance WT, Eastham JA, Savage C, et al. Contemporary open and robotic radical prostatectomy practice patterns among urologists in the United States. J Urol. 2012;187(6):2087-2092.

5. Benbassat J, Taragin M. Hospital re-admissions as a measure of quality of health care: advantages and limitations. Arch Intern Med. 2000;160(8):1074-1081.

6. Epstein AM, Jha AK, Orav EJ. The relationship between hospital admission rates and rehospitalizations. $N$ Engl J Med. 2011;365(24):2287-2295.

7. Jencks SF, Williams MV, Coleman EA. Rehospitalizations among patients in the Medicare fee-for-service program. $N$ Engl J Med. 2009;360(14):1418-1428.

8. Kripalani S, Theobald CN, Anctil B, Vasilevskis EE. Reducing hospital re-admission rates: current strategies and future directions. Annual review of medicine. 2014;65:471485.

9. Cancer Quality Council of Ontario CCOCCOAacociu-h-v-a-c-sa--. Unplanned Hospital Visits and Re-admission After Surgery. 2019.

10. Nakamura MM, Toomey SL, Zaslavsky AM, et al. Measuring Pediatric Hospital Readmission Rates to Drive Quality Improvement. Academic Pediatrics. 2014;14(5, Supplement):S39-S46.

11. Whitney RL, Bell JF, Tancredi DJ, et al. Unplanned Hospitalization Among Individuals With Cancer in the Year After Diagnosis. Journal of oncology practice. 2019;15(1):e20e29.

12. Tsai TC, Joynt KE, Orav EJ, Gawande AA, Jha AK. Variation in Surgical-Re-admission Rates and Quality of Hospital Care. New England Journal of Medicine. 2013;369(12):1134-1142.

13. Lavernia CJ, Villa JM, Iacobelli DA. Re-admission Rates in the State of Florida: A Reflection of Quality? Clinical Orthopaedics and Related Research ${ }^{\circledR}$. 2013;471(12):3856-3862.

14. Fischer C, Lingsma HF, Marang-van de Mheen PJ, Kringos DS, Klazinga NS, Steyerberg EW. Is the Re-admission Rate a Valid Quality Indicator? A Review of the Evidence. PLOS ONE. 2014;9(11):e112282.

15. Press MJ, Scanlon DP, Ryan AM, et al. Limits of re-admission rates in measuring hospital quality suggest the need for added metrics. Health Aff (Millwood). 2013;32(6):1083-1091.

16. van Walraven C, Bennett C, Jennings A, Austin PC, Forster AJ. Proportion of hospital readmissions deemed avoidable: a systematic review. CMAJ : Canadian Medical Association journal = journal de l'Association medicale canadienne. 2011;183(7):E391402. 
17. Auerbach AD, Kripalani S, Vasilevskis EE, et al. Preventability and Causes of Readmissions in a National Cohort of General Medicine Patients. JAMA Intern Med. 2016;176(4):484-493.

18. Moher D, Liberati A, Tetzlaff J, Altman DG. Preferred reporting items for systematic reviews and meta-analyses: the PRISMA statement. PLoS Med. 2009;6(7):e1000097.

19. Rathbone J, Carter M, Hoffmann T, Glasziou P. Better duplicate detection for systematic reviewers: evaluation of Systematic Review Assistant-Deduplication Module. Systematic reviews. 2015;4:6.

20. Higgins JPT TJ, Chandler J, Cumpston M, Li T, Page MJ, Welch VA (editors). Cochrane Handbook for Systematic Reviews of Interventions version 6.1 (updated September 2020). Cochrane, 2020. Available from www.training.cochrane.org/handbook.

21. Abou-Haidar H, Abourbih S, Braganza D, et al. Enhanced recovery pathway for radical prostatectomy: Implementation and evaluation in a universal healthcare system. Canadian Urological Association Journal. 2014;8(11-12):418-423.

22. Afzal MZ, Tobert CM, Bulica E, Noyes SL, Lane BR. Modification of Technique for Suprapubic Catheter Placement After Robot-assisted Radical Prostatectomy Reduces Catheter-associated Complications. Urology. 2015;86(2):401-406.

23. Birch E, van Bruwaene S, Everaerts W, et al. Developing and evaluating Robocare; an innovative, nurse-led robotic prostatectomy care pathway. European Journal of Oncology Nursing. 2016;21:120-125.

24. Brito J, Pereira J, Moreira DM, et al. The association of lymph node dissection with 30day perioperative morbidity among men undergoing minimally invasive radical prostatectomy: analysis of the National Surgical Quality Improvement Program (NSQIP). Prostate Cancer and Prostatic Diseases. 2018:1-7.

25. Chang SS, Cole E, Smith JA, Jr., Baumgartner R, Wells N, Cookson MS. Safely reducing length of stay after open radical retropubic prostatectomy under the guidance of a clinical care pathway. Cancer. 2005;104(4):747-751.

26. Christensen CR, Maatman TK, Maatman TJ, Tran TT. Examining clinical outcomes utilizing low-pressure pneumoperitoneum during robotic-assisted radical prostatectomy. Journal of Robotic Surgery. 2016;10(3):215-219.

27. Chung SD, Kelle JJ, Huang CY, Chen YH, Lin HC. Comparison of 90-day re-admission rates between open retropubic radical prostatectomy (RRP), laparoscopic RP (LRP) and robot-assisted laparoscopic prostatectomy (RALP). BJU International. 2012;110(11 Pt C):E966-971.

28. Coelho RF, Cordeiro MD, Padovani GP, et al. Predictive factors for prolonged hospital stay after retropubic radical prostatectomy in a high-volume teaching center. International braz $j$ urol : official journal of the Brazilian Society of Urology. 2018;44(6):1089-1105.

29. Flannigan RK, Gotto GT, Donnelly B, Carlson KV. Standardized follow-up program may reduce emergency room and urgent care visits for patients undergoing radical prostatectomy. Can Urol Assoc J. 2014;8(7-8):E505-509.

30. Fririksson JO, Holmberg E, Adolfsson J, et al. Rehospitalization after radical prostatectomy in a nationwide, population based study. Journal of Urology. 2014;192(1):112-119. 
31. Gandaglia G, Sammon JD, Chang SL, et al. Comparative effectiveness of robot-assisted and open radical prostatectomy in the postdissemination era. Journal of Clinical Oncology. 2014;32(14):1419-1426.

32. Gralla O, Haas F, Knoll N, et al. Fast-track surgery in laparoscopic radical prostatectomy: basic principles. World J Urol. 2007;25(2):185-191.

33. Hall RM, Linklater N, Coughlin G. Robotic and open radical prostatectomy in the public health sector: cost comparison. ANZ Journal of Surgery. 2014;84(6):477-480.

34. Huang KH, Kaplan AL, Carter SC, Lipsitz SR, Hu JC. The impact of radical prostatectomy operative time on outcomes and costs. Urology. 2014;83(6):1265-1271.

35. Judge A, Evans S, Gunnell DJ, Albertsen PC, Verne J, Martin RM. Patient outcomes and length of hospital stay after radical prostatectomy for prostate cancer: analysis of hospital episodes statistics for England. BJU International. 2007;100(5):1040-1049.

36. Kaufman MR, Smith JA, Jr., Baumgartner RG, et al. Positive influence of robotically assisted laparoscopic prostatectomy on the collaborative-care pathway for open radical prostatectomy. BJU Int. 2006;97(3):473-475.

37. Kaye DR, Syrjamaki J, Ellimoottil C, et al. Use of Routine Home Health Care and Deviations From an Uncomplicated Recovery Pathway After Radical Prostatectomy. Urology. 2018;112:74-79.

38. Kelly M, Sharp L, Dwane F, Kelleher T, Drummond FJ, Comber H. Factors predicting hospital length-of-stay after radical prostatectomy: a population-based study. BMC Health Services Research. 2013;13:244.

39. Kim SP, Gross CP, Smaldone MC, et al. Perioperative outcomes and hospital reimbursement by type of radical prostatectomy: results from a privately insured patient population. Prostate Cancer \& Prostatic Diseases. 2015;18(1):13-17.

40. Kotamarti S, Williams T, Silver M, Silver DA, Schulman AA. Rethinking the need for overnight admission after robotic-assisted laparoscopic prostatectomy. J Robot Surg. 2020;14(6):913-915.

41. Ku TS, Kane CJ, Sen S, Henderson WG, Dudley RA, Cason BA. Effects of hospital procedure volume and resident training on clinical outcomes and resource use in radical retropubic prostatectomy surgery in the Department of Veterans Affairs. J Urol. 2008;179(1):272-278; discussion 278-279.

42. Kubota M, Matsuoka T, Yamasaki T, et al. Effect of Continued Perioperative Anticoagulant Therapy on Bleeding Outcomes Following Robot-assisted Radical Prostatectomy. Urology. 2020.

43. Lasser MS, Renzulli IJ, Turini IGA, Haleblian G, Sax HC, Pareek G. An Unbiased Prospective Report of Perioperative Complications of Robot-assisted Laparoscopic Radical Prostatectomy. Urology. 2010;75(5):1083-1089.

44. Lenfant L, Sawczyn G, Aminsharifi A, et al. Pure Single-site Robot-assisted Radical Prostatectomy Using Single-port Versus Multiport Robotic Radical Prostatectomy: A Single-institution Comparative Study. Eur Urol Focus. 2020.

45. Lin C, Wan F, Lu Y, Li G, Yu L, Wang M. Enhanced recovery after surgery protocol for prostate cancer patients undergoing laparoscopic radical prostatectomy. The Journal of international medical research. 2019;47(1):114-121. 
46. Link BA, Nelson R, Josephson DY, et al. The impact of prostate gland weight in robot assisted laparoscopic radical prostatectomy. J Urol. 2008;180(3):928-932.

47. Lundstrom KJ, Folkvaljon Y, Loeb S, Axelson AB, Stattin P, Nordin P. Small bowel obstruction and abdominal pain after robotic versus open radical prostatectomy. Scandinavian Journal of Urology. 2016;50(3):155-159.

48. Morgan MS, Ozayar A, Friedlander JI, et al. An Assessment of Patient Comfort and Morbidity After Robot-Assisted Radical Prostatectomy with Suprapubic Tube Versus Urethral Catheter Drainage. Journal of Endourology. 2016;30(3):300-305.

49. Moschini M, Gandaglia G, Fossati N, et al. Incidence and Predictors of 30-Day Readmission After Robot-Assisted Radical Prostatectomy. Clinical Genitourinary Cancer. 2017;15(1):67-71.

50. Moschovas MC, Bhat S, Rogers T, et al. Managing Patients with Prostate Cancer During COVID-19 Pandemic: The Experience of a High-Volume Robotic Surgery Center. $J$ Endourol. 2020.

51. Musser JE, Assel MJ, Meeks JJ, et al. Ambulatory Extended Recovery: Safely Transitioning to Overnight Observation for Minimally Invasive Prostatectomy. Urology Practice. 2015;2(3):121-125.

52. Myers SN, Ghani KR, Dunn RL, et al. Notable Outcomes and Trackable Events after Surgery: Evaluating an Uncomplicated Recovery after Radical Prostatectomy. J Urol. 2016;196(2):399-404.

53. Nam RK, Cheung P, Herschorn S, et al. Incidence of complications other than urinary incontinence or erectile dysfunction after radical prostatectomy or radiotherapy for prostate cancer: a population-based cohort study. Lancet Oncology. 2014;15(2):223-231.

54. Nason GJ, Kim JK, Tan GH, Ajib K, Nam RK. Single-night stay for open radical prostatectomy. Can Urol Assoc J. 2020.

55. Nelson B, Kaufman M, Broughton G, et al. Comparison of length of hospital stay between radical retropubic prostatectomy and robotic assisted laparoscopic prostatectomy. Journal of Urology. 2007;177(3):929-931.

56. Niklas C, Saar M, Berg B, et al. da Vinci and Open Radical Prostatectomy: Comparison of Clinical Outcomes and Analysis of Insurance Costs. Urol Int. 2016;96(3):287-294.

57. Paterson C, McLuckie S, Yew-Fung C, Tang B, Lang S, Nabi G. Videotaping of surgical procedures and outcomes following extraperitoneal laparoscopic radical prostatectomy for clinically localized prostate cancer. Journal of Surgical Oncology. 2016;114(8):10161023.

58. Pearce SM, Pariser JJ, Karrison T, Patel SG, Eggener SE. Comparison of Perioperative and Early Oncologic Outcomes between Open and Robotic Assisted Laparoscopic Prostatectomy in a Contemporary Population Based Cohort. J Urol. 2016;196(1):76-81.

59. Pereira JF, Golijanin D, Pareek G, et al. The association of age with perioperative morbidity and mortality among men undergoing radical prostatectomy. Urologic Oncology: Seminars and Original Investigations. 2018;36(4):157.e157-157.e113.

60. Pilecki MA, McGuire BB, Jain U, Kim JY, Nadler RB. National multi-institutional comparison of 30-day postoperative complication and re-admission rates between open retropubic radical prostatectomy and robot-assisted laparoscopic prostatectomy using NSQIP. Journal of Endourology. 2014;28(4):430-436. 
61. Pinochet R, Nogueira L, Cronin AM, et al. Role of short-term antibiotic therapy at the moment of catheter removal after laparoscopic radical prostatectomy. Urologia Internationalis. 2010;85(4):415-420.

62. Ploussard G, Almeras C, Beauval JB, et al. A combination of enhanced recovery after surgery and prehabilitation pathways improves perioperative outcomes and costs for robotic radical prostatectomy. Cancer. 2020;126(18):4148-4155.

63. Ploussard G, Dumonceau O, Thomas L, et al. Multi-Institutional Assessment of Routine Same Day Discharge Surgery for Robot-Assisted Radical Prostatectomy. J Urol. 2020;204(5):956-961.

64. Rabbani F, Yunis LH, Pinochet R, et al. Comprehensive standardized report of complications of retropubic and laparoscopic radical prostatectomy. European Urology. 2010;57(3):371-386.

65. Ruhotina N, Dagenais J, Gandaglia G, et al. The impact of resident involvement in minimally-invasive urologic oncology procedures. Can Urol Assoc J. 2014;8(9-10):334340.

66. Schmid M, Chiang HA, Sood A, et al. Causes of hospital re-admissions after urologic cancer surgery. Urologic Oncology. 2016;34(5):236.e231-211.

67. Schmid M, Meyer CP, Reznor G, et al. Racial Differences in the Surgical Care of Medicare Beneficiaries With Localized Prostate Cancer. JAMA Oncology. 2016;2(1):8593.

68. Schommer E, Tonkovich K, Li Z, Thiel DD. Impact of Resident Involvement on RobotAssisted Radical Prostatectomy Outcomes. Journal of Endourology. 2016;30(10):11261131.

69. Seveso M, Melegari S, Bozzini G, De Francesco O, Mandressi A, Taverna G. Does site of specimen extraction affect incisional hernia rate after robot assisted laparoscopic radical prostatectomy? International Journal of Surgery. 2017;47:96-100.

70. Sood A, Meyer CP, Abdollah F, et al. Minimally invasive surgery and its impact on 30day postoperative complications, unplanned re-admissions and mortality. The British journal of surgery. 2017;104(10):1372-1381.

71. Sujenthiran A, Charman SC, Parry M, et al. Quantifying severe urinary complications after radical prostatectomy: the development and validation of a surgical performance indicator using hospital administrative data. BJU International. 2017;120(2):219-225.

72. Thiel DD, Chavez M, Brisson TE. Transition from resident robotic training program to clinical practice: Robotic-assisted radical prostatectomy benchmark for perioperative safety. Journal of Laparoendoscopic and Advanced Surgical Techniques. 2013;23(6):516-520.

73. Thiel DD, Hutchinson R, Diehl N, Tavlarides A, Williams A, Parker AS. Impact of fellowship training on one-year outcomes of robotic-assisted prostatectomy. Journal of the Society of Laparoendoscopic Surgeons. 2012;16(2):195-201.

74. Tollefson MK, Frank I, Gettman MT. Robotic-assisted radical prostatectomy decreases the incidence and morbidity of surgical site infections. Urology. 2011;78(4):827-831.

75. Touijer K, Eastham JA, Secin FP, et al. Comprehensive prospective comparative analysis of outcomes between open and laparoscopic radical prostatectomy conducted in 2003 to 2005. Journal of Urology. 2008;179(5):1811-1817; discussion 1817. 
76. Turini GA, Clark MA, Machan J, Tucci C, Renzulli JF. The Role of a Standardized Clinical Care Pathway in Patient Satisfaction and Quality of Life Outcomes after Robotic Assisted Laparoscopic Radical Prostatectomy. Urology Practice. 2017;4(3):232-238.

77. Tyritzis SI, Wallerstedt A, Steineck G, et al. Thromboembolic Complications in 3,544 Patients Undergoing Radical Prostatectomy with or without Lymph Node Dissection. Journal of Urology. 2015;193(1):117-125.

78. Wallerstedt A, Tyritzis SI, Thorsteinsdottir T, et al. Short-term results after robot-assisted laparoscopic radical prostatectomy compared to open radical prostatectomy. Eur Urol. 2015;67(4):660-670.

79. Wallerstedt Lantz A, Stranne J, Tyritzis SI, et al. 90-Day re-admission after radical prostatectomy-a prospective comparison between robot-assisted and open surgery. Scand J Urol. 2019:1-8.

80. Xia L, Taylor BL, Patel NA, et al. Concurrent inguinal hernia repair in patients undergoing minimally invasive radical prostatectomy: A national surgical quality improvement program study. Journal of Endourology. 2018;32(7):665-670.

81. Glance LG, Kellermann AL, Osler TM, et al. Hospital re-admission after noncardiac surgery: the role of major complications. JAMA Surgery. 2014;149(5):439-445.

82. Kohlnhofer BM, Tevis SE, Weber SM, Kennedy GD. Multiple complications and short length of stay are associated with postoperative re-admissions. Am J Surg. 2014;207(4):449-456.

83. Lucas DJ, Haider A, Haut E, et al. Assessing re-admission after general, vascular, and thoracic surgery using ACS-NSQIP. Ann Surg. 2013;258(3):430-439.

84. Lv Z, Cai Y, Jiang H, et al. Impact of enhanced recovery after surgery or fast track surgery pathways in minimally invasive radical prostatectomy: a systematic review and meta-analysis. Transl Androl Urol. 2020;9(3):1037-1052.

85. Zhao Y, Zhang S, Liu B, Li J, Hong H. Clinical efficacy of enhanced recovery after surgery (ERAS) program in patients undergoing radical prostatectomy: a systematic review and meta-analysis. World Journal of Surgical Oncology. 2020;18(1):131.

86. Alibhai SMH, Leach M, Tomlinson G, et al. 30-Day Mortality and Major Complications after Radical Prostatectomy: Influence of Age and Comorbidity. JNCI: Journal of the National Cancer Institute. 2005;97(20):1525-1532.

87. Merhe A, Abou Heidar N, Hout M, et al. An evaluation of the timing of surgical complications following radical prostatectomy: Data from the American College of Surgeons National Surgical Quality Improvement Program (ACS-NSQIP). Arab J Urol. 2020;18(3):136-141.

88. Braet A, Weltens C, Sermeus W. Effectiveness of discharge interventions from hospital to home on hospital re-admissions: a systematic review. JBI Database System Rev Implement Rep. 2016;14(2):106-173.

89. Hansen LO, Young RS, Hinami K, Leung A, Williams MV. Interventions to reduce 30day rehospitalization: a systematic review. Annals of internal medicine. 2011;155(8):520528.

90. Leppin AL, Gionfriddo MR, Kessler M, et al. Preventing 30-day hospital re-admissions: a systematic review and meta-analysis of randomized trials. JAMA Intern Med. 2014;174(7):1095-1107. 
91. Gani F, Lucas DJ, Kim Y, Schneider EB, Pawlik TM. Understanding Variation in 30-Day Surgical Re-admission in the Era of Accountable Care: Effect of the Patient, Surgeon, and Surgical Subspecialties. JAMA Surg. 2015;150(11):1042-1049. 


\section{Figures and Tables}

Fig. 1. PRISMA flow diagram and radical prostatectomy (RP) patient breakdown. *Inclusion/exclusion criteria are highlighted in methods section.

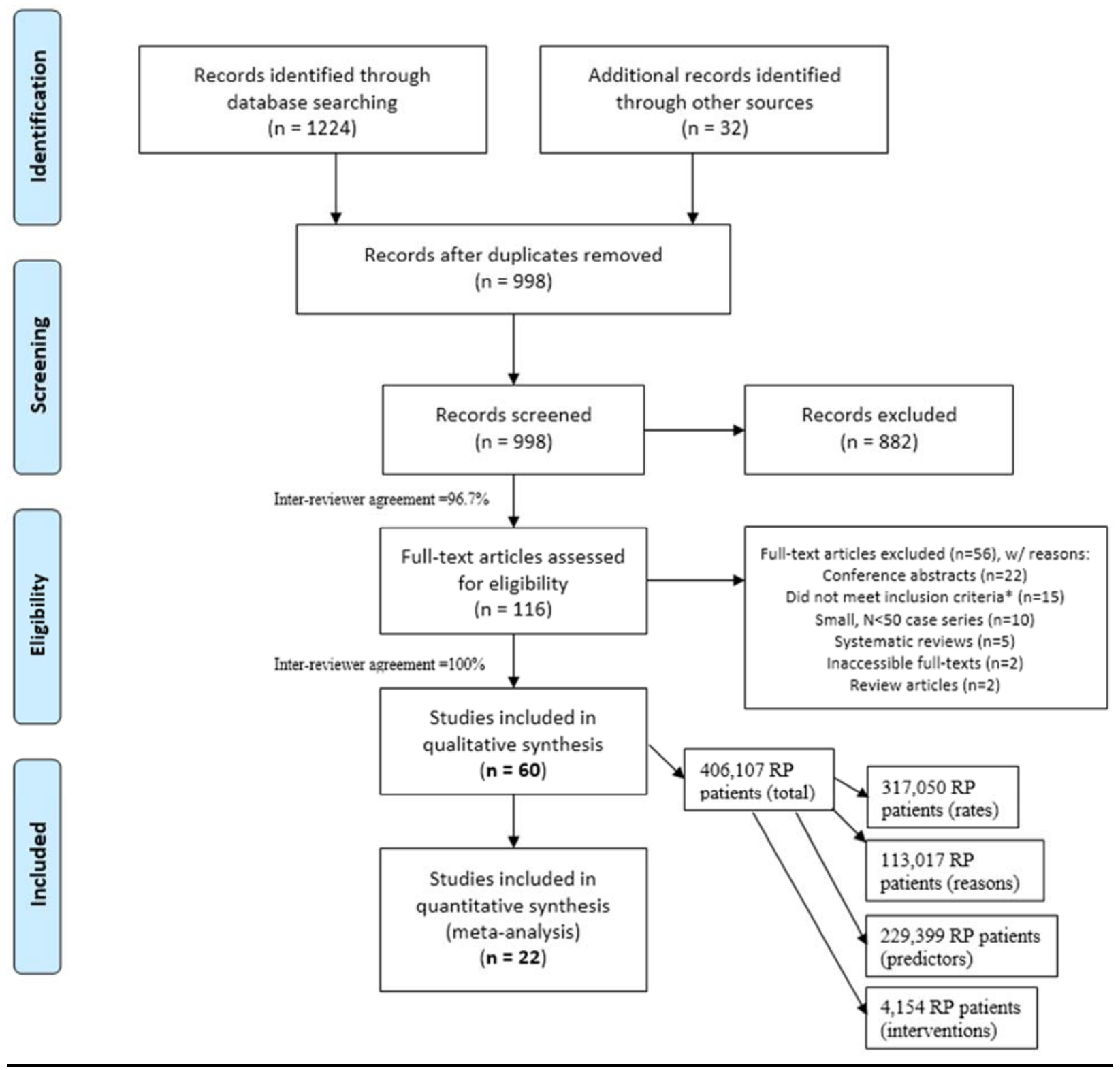


Fig. 2. Meta-analysis of interventions to reduce (all-cause/endpoint) unplanned visits after radical prostatectomy ( $\mathrm{RP})(\mathrm{n}=10$ studies). The overall effect favored the interventions at reducing unplanned visits in this meta-analysis as shown by the (a) forest and (b) funnel plots. The overall effect estimate of the ten tested interventions was 0.62 (95\% confidence interval [CI] 0.46-0.84) (FE: $\mathrm{p}=0.002$; RE: $\mathrm{p}=0.008$ ) for the unplanned visit (re-admission or emergency room $[E R]$ visit) event outcome. There was no detection of heterogeneity $(\mathrm{Q}=7.3017, \mathrm{p}=0.6057$; $\mathrm{I}^{2}=0.00 \%[0-53.86 \%]$ ) or publication bias (Egger's $\mathrm{p}=0.6315$; Begg's $\mathrm{p}=0.4208$ ). The overall low quality of the included studies resulted in a high risk of bias; risk of bias is outlined in the right of the forest plot. All plots were generated using RevMan (v.5.4.1) and testing of publication bias was conducted using MedCalc (v.19.1.1). ${ }^{*}$ The Birch et al 2016 study did not have a control group, so we used back calculation - while matching their intervention group sample size of $\mathrm{n}=124$ - through the overall 90 -day RDM rate for all RP patients, to calculate a hypothetical one. ${ }^{* *}$ The Kubota et al 2020 study compared four different groups of patients, and mainly focused on bleeding outcomes and perhaps as a result did not consider re-admission as a primary outcome. ${ }^{* * *}$ Re-admission or ER visit were reported as secondary outcomes of interest in most studies. (c) Unplanned visits (UPV) rates were calculated for all case-control studies as dichotomous event outcomes. Line plots were generated, and rates summarized in the table below the line graph. (d) Paired t-test shows that the intervention group had a significantly lower UPV rate than their paired controls. Mean of differences $=3.39 \%$ (95\% CI 0.01-6.69\%), $\mathrm{p}=0.0455$, pairing effectiveness, $\mathrm{p}<0.0001$.

a.

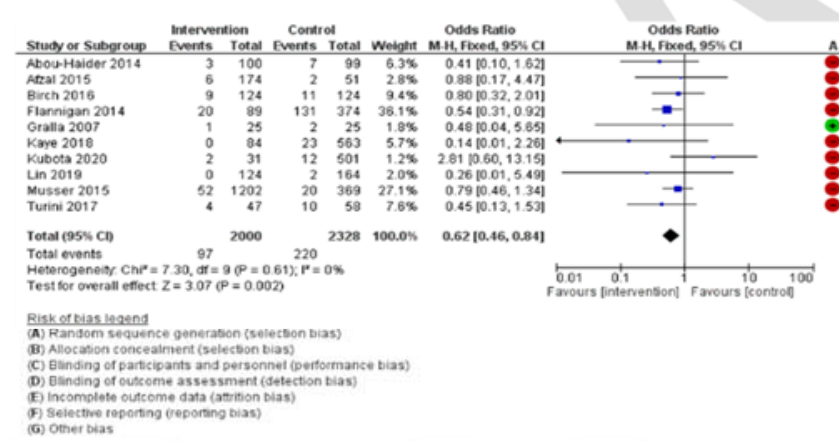

c.

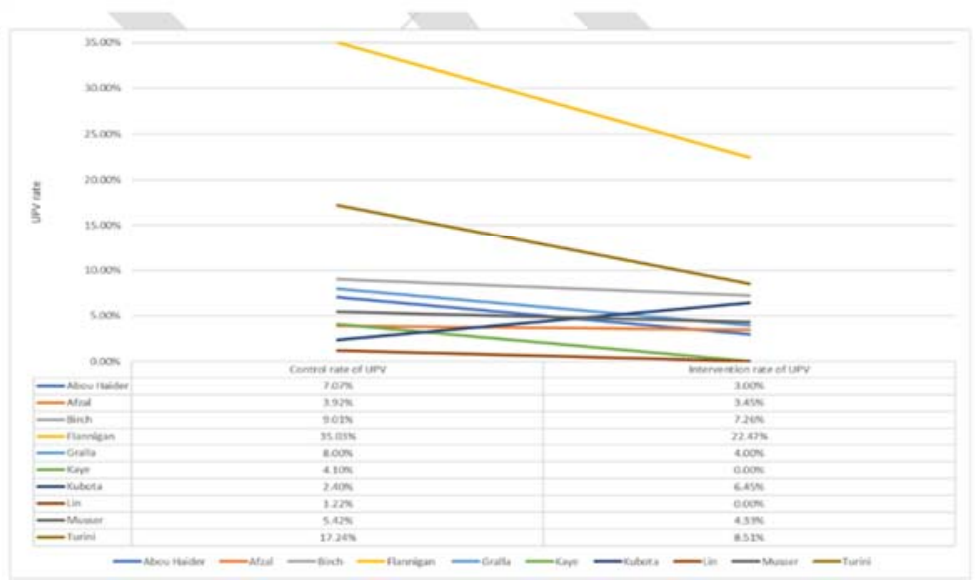

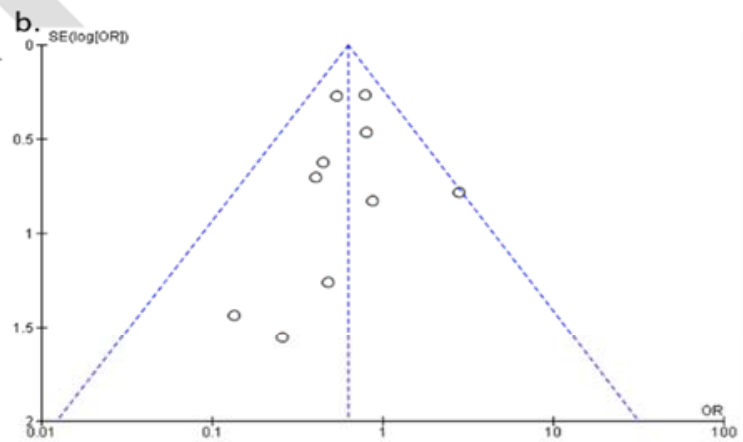

d.

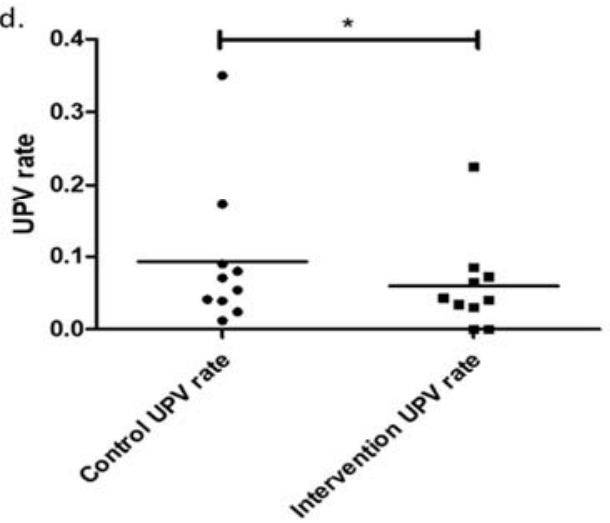




\begin{tabular}{|c|c|c|c|c|c|}
\hline $\begin{array}{l}\text { Author \& } \\
\text { year }\end{array}$ & $\begin{array}{l}\text { Data source } \\
\text { and/or scope } \\
\text { (country) }\end{array}$ & $\begin{array}{l}\text { Total RP } \\
\text { sample } \\
\text { size (n) }\end{array}$ & $\begin{array}{l}\text { Sample sizes by } \\
\text { surgical } \\
\text { approaches (n) }\end{array}$ & $\begin{array}{c}\text { Re-admission rate } \\
\text { (events/total, rate [\%], } \\
\text { endpoint) }\end{array}$ & $\begin{array}{c}\text { Emergency room Visit rate } \\
\text { (events/total, rate [\%], } \\
\text { endpoint) }\end{array}$ \\
\hline $\begin{array}{l}\text { Abou-Haidar } \\
2014\end{array}$ & $\begin{array}{l}\text { Single-center } \\
\text { (Canada) }\end{array}$ & 199 & $\begin{array}{l}\text { RRP (73) } \\
\operatorname{LRP}(35) \\
\operatorname{RARP}(91)\end{array}$ & $\begin{array}{c}10 / 199(5.03 \%) \\
90-\text { day }\end{array}$ & $\begin{array}{c}24 / 199(12.06 \%) \\
90-\text { day }\end{array}$ \\
\hline Afzal 2015 & $\begin{array}{l}\text { Single-center } \\
\text { (U.S.) }\end{array}$ & 225 & RARP (225) & $\begin{array}{c}8 / 225(3.56 \%) \\
30 \text {-day }\end{array}$ & $\begin{array}{c}\text { 29/225 (12.89\%) } \\
\text { 30-day }\end{array}$ \\
\hline Birch 2016 & $\begin{array}{l}\text { Single-center } \\
\text { (Australia) }\end{array}$ & 124 & RARP (124) & $\begin{array}{c}9 / 124(7.23 \%)^{*} \\
\text { Unknown endpoint }\end{array}$ & - \\
\hline Brito 2018 & $\begin{array}{c}\text { ACS-NSQIP } \\
\text { Database (U.S.) }\end{array}$ & 29,012 & RARP $(29,012)$ & $\begin{array}{c}860 / \mathrm{X}(3.8 \%) \\
\text { 30-day }\end{array}$ & - \\
\hline Chang 2005 & $\begin{array}{l}\text { Single-center } \\
\text { (U.S.A) }\end{array}$ & 994 & RRP (994) & $\begin{array}{c}\text { X/994 (3.0\%) } \\
\text { 30-day }\end{array}$ & - \\
\hline $\begin{array}{l}\text { Christensen } \\
2016\end{array}$ & $\begin{array}{l}\text { Single-center } \\
\text { (U.S.) }\end{array}$ & 200 & RARP (200) & $\begin{array}{c}7 / 200(3.50 \%)^{*} \\
\text { Unknown endpoint }\end{array}$ & - \\
\hline Chung 2012 & $\begin{array}{c}\text { National Health } \\
\text { Insurance }\end{array}$ & 2741 & $\begin{array}{l}\text { RRP (1173) } \\
\operatorname{RARP}(274)\end{array}$ & $\begin{array}{c}257 / 2741(9.34 \%) \\
90-\text { day }\end{array}$ & - \\
\hline
\end{tabular}


Mukkala et al

Unplanned visits after radical prostatectomy

\begin{tabular}{|c|c|c|c|c|c|}
\hline & $\begin{array}{l}\text { Research } \\
\text { Database } \\
\text { (Taiwan) }\end{array}$ & & LRP (694) & & \\
\hline Coelho 2018 & $\begin{array}{l}\text { Single-center } \\
\text { (Brazil) }\end{array}$ & 1011 & RRP (1011) & $\begin{array}{c}28 / 1011(2.7 \%) \\
28 \text {-day }\end{array}$ & $\begin{array}{c}\text { 74/1011 (7.3\%) } \\
\text { Unknown endpoint }\end{array}$ \\
\hline $\begin{array}{l}\text { Flannigan } \\
2014\end{array}$ & $\begin{array}{l}\text { Single-center } \\
\text { (Canada) }\end{array}$ & 436 & $\begin{array}{l}\text { RRP (274) } \\
\text { LRP (47) } \\
\text { ORP (115) }\end{array}$ & $\begin{array}{c}15 / 321(4.67 \%) \\
90 \text {-day }\end{array}$ & $\begin{array}{c}77 / 321(23.99 \%) \\
90 \text {-day }\end{array}$ \\
\hline $\begin{array}{l}\text { Friðriksson } \\
2014\end{array}$ & $\begin{array}{c}\text { Prostate Cancer } \\
\text { Database Sweden } \\
\text { (Sweden })\end{array}$ & 24122 & $\begin{array}{l}\operatorname{RRP}(16375) \\
\operatorname{RARP}(6393) \\
\operatorname{LRP}(1354)\end{array}$ & $\begin{array}{c}2,317 / 24122(9.61 \%) \\
90-\text { day }\end{array}$ & - \\
\hline $\begin{array}{l}\text { Gandaglia } \\
2014\end{array}$ & $\begin{array}{l}\text { SEER Database } \\
\text { (U.S.) }\end{array}$ & 5015 & $\begin{array}{c}\text { ORP (2357) } \\
\text { RARP (3429) }\end{array}$ & $\begin{array}{c}230 / 5915(3.89 \%) \\
30-\text { day } \\
334 / 5915(5.65 \%) \\
90-\text { day }\end{array}$ & - \\
\hline Gralla 2007 & $\begin{array}{l}\text { Single-center } \\
\text { (Germany) }\end{array}$ & 50 & LRP (50) & $\begin{array}{c}3 / 50(6.00 \%) \\
\text { Unknown endpoint }\end{array}$ & - \\
\hline Hall 2014 & $\begin{array}{l}\text { Single-center } \\
\text { (Australia) }\end{array}$ & 200 & $\begin{array}{l}\text { ORP }(100) \\
\operatorname{RARP}(100)\end{array}$ & $\begin{array}{l}21 / 200(10.50 \%)^{*} \\
\text { Unknown endpoint }\end{array}$ & - \\
\hline Huang 2014 & $\begin{array}{l}\text { SEER Database } \\
\text { (U.S.) }\end{array}$ & 7534 & $\begin{array}{l}\operatorname{RRP}(4720) \\
\operatorname{RPP}(324)\end{array}$ & $\begin{array}{c}554 / 7534(7.35 \%) \\
90-\text { day }\end{array}$ & $\begin{array}{c}\text { 1,030/7534 (13.67\%) } \\
\text { 90-day }\end{array}$ \\
\hline
\end{tabular}


Mukkala et al

Unplanned visits after radical prostatectomy

\begin{tabular}{|c|c|c|c|c|c|}
\hline & & & MIRP (2490) & & \\
\hline Judge 2007 & $\begin{array}{c}\text { Hospital Episode } \\
\text { Statistics database } \\
\text { (U.K.) }\end{array}$ & 18027 & RP (18 027) & $\begin{array}{c}2,964 / 14,590(20.32 \%)^{*} \\
\text { 1-year }\end{array}$ & - \\
\hline $\begin{array}{l}\text { Kaufman } \\
2006\end{array}$ & $\begin{array}{l}\text { Single-center } \\
\text { (USA) }\end{array}$ & 379 & $\begin{array}{l}\text { RRP (183) } \\
\text { RARP (196) }\end{array}$ & $\begin{array}{c}10 / 262(3.82 \%) \\
30-\text { day }\end{array}$ & - \\
\hline Kaye 2018 & $\begin{array}{c}\text { Statewide, } \\
\text { MUSIC (U.S.) }\end{array}$ & 647 & RARP (647) & $\begin{array}{c}\mathrm{X} / 647(4 \%)^{*} \\
16 \text {-day }\end{array}$ & $\begin{array}{c}\mathrm{X} / 647(22.4 \%)^{*} \\
16 \text {-day }\end{array}$ \\
\hline Kelly 2013 & $\begin{array}{c}\text { Irish Cancer } \\
\text { Registry (Ireland) }\end{array}$ & 2411 & RP (2411) & $\begin{array}{c}854 / 1,535(55.64 \%) \\
28 \text {-day }\end{array}$ & - \\
\hline Kim 2015 & $\begin{array}{c}\text { IMS LifeLink } \\
\text { Health Plan } \\
\text { Claims Database } \\
\text { (U.S.) }\end{array}$ & 17610 & $\begin{array}{l}\text { MIRP (8981) } \\
\text { ORP (8629) }\end{array}$ & $\begin{array}{c}\mathrm{X} / 17,610(10.5 \%) \\
90-\text { day }\end{array}$ & - \\
\hline $\begin{array}{l}\text { Kotomari } \\
2020\end{array}$ & $\begin{array}{l}\text { Single-center } \\
\text { (U.S.) }\end{array}$ & 613 & RARP (613) & $\begin{array}{c}21 / 613(3.43 \%) \\
30-\text { day }\end{array}$ & - \\
\hline Ku 2008 & $\begin{array}{c}\text { ACS-NSQIP } \\
\text { Database (U.S.) }\end{array}$ & 5736 & RRP (5736) & $\begin{array}{c}133 / 5,736(2.32 \%)^{*} \\
\text { 14-day }\end{array}$ & - \\
\hline Kubota 2020 & $\begin{array}{l}\text { Single-center } \\
\text { (Japan) }\end{array}$ & 606 & RARP (606) & $\begin{array}{c}16 / 6060(2.64 \%) \\
\text { Unknown endpoint }\end{array}$ & - \\
\hline
\end{tabular}


Mukkala et al

Unplanned visits after radical prostatectomy

\begin{tabular}{|c|c|c|c|c|c|}
\hline Lasser 2010 & $\begin{array}{l}\text { Single-center } \\
\text { (U.S.) }\end{array}$ & 239 & RARP (239) & $\begin{array}{c}1 / 239(0.42 \%) \\
30 \text {-day }\end{array}$ & - \\
\hline Lenfant 2020 & $\begin{array}{l}\text { Single-center } \\
\text { (U.S.) }\end{array}$ & 210 & RARP (210) & $\begin{array}{c}15 / 210(7.14 \%) \\
30 \text {-day }\end{array}$ & - \\
\hline Lin 2019 & $\begin{array}{l}\text { Single-center } \\
\text { (China) }\end{array}$ & 288 & LRP (288) & $\begin{array}{c}2 / 288(0.69 \%) \\
90 \text {-day }\end{array}$ & - \\
\hline Link 2008 & $\begin{array}{l}\text { Single-center } \\
\text { (U.S.) }\end{array}$ & 1847 & RARP (1847) & $\begin{array}{l}46 / 1,847(2.49 \%)^{*} \\
\text { Unknown endpoint }\end{array}$ & - \\
\hline $\begin{array}{l}\text { Lundstrom } \\
2016\end{array}$ & $\begin{array}{c}\text { Prostate Cancer } \\
\text { Database Sweden } \\
\text { (Sweden) }\end{array}$ & 17043 & $\begin{array}{c}\text { RRP (9787) } \\
\text { RARP (7256) }\end{array}$ & $\begin{array}{c}\text { 97/17,043 }(0.57 \%) \\
\text { 30-day }\end{array}$ & - \\
\hline $\begin{array}{l}\text { Morgan } \\
2016\end{array}$ & $\begin{array}{l}\text { Single-center } \\
\text { (U.S.) }\end{array}$ & 159 & RARP (159) & $\begin{array}{c}0 / 159(0.00 \%)^{*} \\
\text { Unknown endpoint }\end{array}$ & $\begin{array}{c}\text { 10/159 }(6.29 \%)^{*} \\
\text { Unknown endpoint }\end{array}$ \\
\hline $\begin{array}{l}\text { Moschini } \\
2017\end{array}$ & $\begin{array}{l}\text { Single-center } \\
\text { (Italy) }\end{array}$ & 1407 & RARP (1402) & $\begin{array}{c}38 / 1,402(2.71 \%) \\
30 \text {-day }\end{array}$ & - \\
\hline $\begin{array}{l}\text { Moschovas } \\
2020\end{array}$ & $\begin{array}{l}\text { Single-center } \\
\text { (U.S.) }\end{array}$ & 147 & RARP (147) & $\begin{array}{c}\text { 2/147 (1.36\%) } \\
\text { Unknown endpoint }\end{array}$ & - \\
\hline Musser 2015 & $\begin{array}{l}\text { Single-center } \\
\quad \text { (U.S.) }\end{array}$ & 1571 & $\begin{array}{c}\text { RARP (1191) } \\
\text { LRP (380) }\end{array}$ & $\begin{array}{c}72 / 1,571(4.58 \%) \\
\text { 30-day }\end{array}$ & $\begin{array}{c}178 / 1571(11.33 \%) \\
\text { 30-day }\end{array}$ \\
\hline
\end{tabular}


Mukkala et al

Unplanned visits after radical prostatectomy

\begin{tabular}{|c|c|c|c|c|c|}
\hline Myers 2016 & $\begin{array}{c}\text { Statewide, } \\
\text { MUSIC (U.S.) }\end{array}$ & 2,245 & $\begin{array}{c}\text { ORP (92) } \\
\operatorname{MIRP}(2153)\end{array}$ & $\begin{array}{c}92 / 2,245(4.10 \%) \\
\text { 30-day }\end{array}$ & - \\
\hline Nam 2014 & OHIP (Canada) & 15870 & ORP (15 870) & $\begin{array}{c}2,749 / 15870(17.32 \%)^{*} \\
\text { 5-year }\end{array}$ & - \\
\hline Nason 2020 & $\begin{array}{l}\text { Single-center } \\
\text { (Canada) }\end{array}$ & 581 & ORP (581) & $\begin{array}{c}22 / 581(3.79 \%) \\
30-\text { day }\end{array}$ & $\begin{array}{c}\text { 46/581 }(7.92 \%) \\
\text { Unknown endpoint }\end{array}$ \\
\hline Nelson 2007 & $\begin{array}{l}\text { Single-center } \\
\text { (U.S.) }\end{array}$ & 1003 & $\begin{array}{l}\operatorname{RRP}(374) \\
\operatorname{RARP}(629)\end{array}$ & $\begin{array}{c}63 / 1003(6.28 \%)^{*} \\
\text { Unknown endpoint }\end{array}$ & $\begin{array}{l}\text { 100/1003 }(9.97 \%)^{*} \\
\text { Unknown endpoint }\end{array}$ \\
\hline Niklas 2016 & $\begin{array}{l}\text { Single-center } \\
\text { (Germany) }\end{array}$ & 1431 & $\begin{array}{l}\text { RRP (499) } \\
\text { RARP (932) }\end{array}$ & $\begin{array}{c}224 / 1431(15.65 \%) \\
\text { 30-day }\end{array}$ & - \\
\hline $\begin{array}{l}\text { Paterson } \\
2016\end{array}$ & $\begin{array}{l}\text { Single-center } \\
\text { (Scotland) }\end{array}$ & 200 & LRP (200) & $\begin{array}{c}18 / 200(9.00 \%) \\
90 \text {-day }\end{array}$ & - \\
\hline Pearce 2016 & $\begin{array}{l}\text { National Cancer } \\
\text { Database (U.S.) }\end{array}$ & 96935 & $\begin{array}{c}\text { ORP (23 804) } \\
\text { RARP (73 131) }\end{array}$ & $\begin{array}{c}2,875 / 96935(2.97 \%) \\
\text { 30-day }\end{array}$ & - \\
\hline Pereira 2018 & $\begin{array}{c}\text { ACS-NSQIP } \\
\text { (U.S.) }\end{array}$ & 35968 & RP (35 968) & $\begin{array}{c}1,439 / 35968(4.00 \%) \\
\text { 30-day }\end{array}$ & - \\
\hline Pilecki 2014 & $\begin{array}{l}\text { ACS-NSQIP } \\
\text { (U.S.) }\end{array}$ & 5471 & $\begin{array}{l}\text { RRP (1097) } \\
\text { RARP (4374) }\end{array}$ & $\begin{array}{c}\text { 212/5471 (3.87\%) } \\
\text { 30-day }\end{array}$ & - \\
\hline
\end{tabular}


Mukkala et al

Unplanned visits after radical prostatectomy

\begin{tabular}{|c|c|c|c|c|c|}
\hline $\begin{array}{l}\text { Pinochet } \\
2010\end{array}$ & $\begin{array}{l}\text { Single-center } \\
\text { (U.S.) }\end{array}$ & 729 & MIRP (729) & $\begin{array}{c}54 / 729(7.41 \%) \\
\text { 30-day }\end{array}$ & $\begin{array}{c}106 / 729(14.54 \%) \\
\text { 30-day }\end{array}$ \\
\hline $\begin{array}{l}\text { Ploussard } \\
2020 \mathrm{a}\end{array}$ & $\begin{array}{l}\text { Single-center } \\
\text { (France) }\end{array}$ & 507 & RARP (507) & $\begin{array}{c}\mathrm{X} / 507(7.9 \%) \\
90-\text { day }\end{array}$ & - \\
\hline $\begin{array}{l}\text { Ploussard } \\
2020 \mathrm{~b}\end{array}$ & $\begin{array}{l}\text { Multicenter } \\
\text { (France) }\end{array}$ & 358 & RARP (358) & $\begin{array}{c}10 / 358(2.79 \%) \\
30 \text {-day }\end{array}$ & - \\
\hline $\begin{array}{l}\text { Rabbani } \\
2010\end{array}$ & $\begin{array}{l}\text { Single-center } \\
\text { (U.S.) }\end{array}$ & 4592 & $\begin{array}{l}\text { RRP (3458) } \\
\text { MIRP (1134) }\end{array}$ & $\begin{array}{l}{ }^{*} 240 / 4592(5.23 \%) \\
\text { Unknown endpoint }\end{array}$ & $\begin{array}{c}* 652 / 4592(14.20 \%) \\
\text { Unknown endpoint }\end{array}$ \\
\hline $\begin{array}{l}\text { Ruhotina } \\
2014\end{array}$ & $\begin{array}{l}\text { ACS-NSQIP } \\
\text { (U.S.) }\end{array}$ & 5459 & MIRP (5459) & $\begin{array}{c}55 / 1467(3.75 \%) \\
30-\text { day }\end{array}$ & - \\
\hline $\begin{array}{l}\text { Schmid } \\
\text { 2016a }\end{array}$ & $\begin{array}{l}\text { ACS-NSQIP } \\
\text { (U.S.) }\end{array}$ & 5428 & $\begin{array}{l}\text { ORP (1204) } \\
\text { MIRP (4224) }\end{array}$ & $\begin{array}{c}221 / 5428(4.07 \%) \\
30 \text {-day }\end{array}$ & - \\
\hline $\begin{array}{l}\text { Schmid } \\
2016 b\end{array}$ & $\begin{array}{l}\text { SEER-Medicare } \\
\text { Database (U.S.) }\end{array}$ & 26482 & $\mathrm{RP}(26482)$ & - & - \\
\hline $\begin{array}{l}\text { Schommer } \\
2016\end{array}$ & $\begin{array}{l}\text { Single-center } \\
\text { (U.S.) }\end{array}$ & 372 & RARP (372) & $\begin{array}{c}14 / 372(3.76 \%) \\
\text { 30-day }\end{array}$ & - \\
\hline Seveso 2017 & $\begin{array}{l}\text { Single-center } \\
\text { (Italy) }\end{array}$ & 800 & RARP (800) & $\begin{array}{c}9 / 800(0.11 \%) \\
\text { 30-day }\end{array}$ & - \\
\hline Sood 2017 & $\begin{array}{l}\text { ACS-NSQIP } \\
\text { (USA) }\end{array}$ & 10802 & $\begin{array}{l}\text { ORP }(5401) \\
\operatorname{MIRP}(5401)\end{array}$ & $\begin{array}{c}360 / 8028(4.45 \%) \\
\text { 30-day }\end{array}$ & - \\
\hline
\end{tabular}


Mukkala et al

Unplanned visits after radical prostatectomy

\begin{tabular}{|c|c|c|c|c|c|}
\hline $\begin{array}{l}\text { Sujenthiran } \\
2017\end{array}$ & $\begin{array}{l}\text { Hospital Episode } \\
\text { Statistics (U.K.) }\end{array}$ & 17299 & $\begin{array}{c}\text { LRP (5479) } \\
\text { ORP (6873) } \\
\text { RARP (4949) }\end{array}$ & $\begin{array}{c}\text { *2695/17 } 299(15.58 \%) \\
\text { 2-year }\end{array}$ & - \\
\hline Thiel 2012 & $\begin{array}{l}\text { Single-center } \\
\text { (U.S.) }\end{array}$ & 100 & RARP (100) & $\begin{array}{c}\text { * 5/100 (5.00\%) } \\
\text { Unknown endpoint }\end{array}$ & - \\
\hline Thiel 2013 & $\begin{array}{l}\text { Single-center } \\
\text { (U.S.) }\end{array}$ & 100 & RARP (100) & $\begin{array}{c}{ }^{*} 0 / 100(0 \%) \\
\text { 14-day }\end{array}$ & - \\
\hline $\begin{array}{l}\text { Tollefson } \\
2011\end{array}$ & $\begin{array}{l}\text { Single-center } \\
\text { (U.S.) }\end{array}$ & 5908 & $\begin{array}{l}\text { RRP (4824) } \\
\text { RARP (1084) }\end{array}$ & $\begin{array}{l}\text { *11/5908 }(0.19 \%) \\
\text { Unknown endpoint }\end{array}$ & - \\
\hline Touijer 2008 & $\begin{array}{l}\text { Single-center } \\
\text { (U.S.) }\end{array}$ & 1430 & $\begin{array}{l}\operatorname{RRP}(818) \\
\operatorname{LRP}(612)\end{array}$ & $\begin{array}{c}30 / 1162(2.58 \%) \\
\text { 30-day }\end{array}$ & $\begin{array}{c}150 / 1,430(10.49 \%) \\
30 \text {-day }\end{array}$ \\
\hline Turini 2017 & $\begin{array}{l}\text { Single-center } \\
\text { (U.S.) }\end{array}$ & 105 & RARP (105) & -1 & $\begin{array}{l}{ }^{*} 14 / 105(13.33 \%) \\
\text { Unknown endpoint }\end{array}$ \\
\hline Tyritzis 2015 & $\begin{array}{c}\text { Multicenter, } \\
\text { LAPRO (Sweden) }\end{array}$ & 3544 & $\begin{array}{c}\text { ORP }(863) \\
\text { RARP }(2681)\end{array}$ & $\begin{array}{c}255 / 3544(7.20 \%) \\
90-\text { day }\end{array}$ & - \\
\hline $\begin{array}{l}\text { Wallerstedt } \\
2015\end{array}$ & $\begin{array}{c}\text { Multicenter } \\
\text { (Sweden) }\end{array}$ & 2625 & $\begin{array}{c}\text { RRP (778) } \\
\text { RARP (1847) }\end{array}$ & $\begin{array}{c}220 / 2506(8.78 \%) \\
90-\text { day }\end{array}$ & - \\
\hline Xia 2018 & $\begin{array}{l}\text { ACS-NSQIP } \\
\quad \text { (U.S.) }\end{array}$ & 18065 & MIRP (18 065) & $\begin{array}{c}\text { 639/18 } 065(3.56 \%) \\
\text { 30-day }\end{array}$ & - \\
\hline
\end{tabular}

The collective data of $406107 \mathrm{RP}$ patients is summarized here; 50.3\% underwent MIRP (including 36.0\% RARP), 28.9\% underwent open procedures, and $20.8 \%$ were unspecified RP. ${ }^{*}$ Irregular rate values due to unusual (not 30-day or 90-day) or unknown UPV 
endpoints. X indicates values which were not available from the reference study. LRP: laparoscopic radical prostatectomy; MIRP: minimally invasive radical prostatectomy; ORP: open radical prostatectomy; RARP: robot assisted radical prostatectomy; RPP: radical perineal prostatectomy; RRP: radical retropubic prostatectomy; UPV: unplanned visit. 


\begin{tabular}{|c|c|c|c|c|c|c|c|c|}
\hline UPV category & $\begin{array}{c}\text { Re- } \\
\text { admission } \\
\text { events }\end{array}$ & $\begin{array}{l}\text { Total } \\
\text { RPs }\end{array}$ & $\begin{array}{l}\text { \% of total } \\
\text { re- } \\
\text { admissions }\end{array}$ & $\begin{array}{l}\text { \% of } \\
\text { total } \\
\text { RPs }\end{array}$ & $\begin{array}{c}\text { ER } \\
\text { visit } \\
\text { events }\end{array}$ & $\begin{array}{l}\text { Total } \\
\text { RPs }\end{array}$ & $\begin{array}{c}\text { \% of } \\
\text { total ER } \\
\text { visits }\end{array}$ & $\begin{array}{l}\text { \% of } \\
\text { total } \\
\text { RPs }\end{array}$ \\
\hline $\begin{array}{l}\text { GU-related complications and } \\
\text { issues }^{29,30,35,36,44,49,51,53,57,64,66,71,77,78}\end{array}$ & 8187 & 93515 & $55.29 \%$ & $8.75 \%$ & 310 & 6563 & $36.34 \%$ & $4.72 \%$ \\
\hline $\begin{array}{l}\text { Bladder-related complications } \\
\text { (stricture, stones, rupture, stenosis) }\end{array}$ & 765 & 31631 & 5 & $2.42 \%$ & - & - & - & - \\
\hline $\begin{array}{l}\text { Renal problems (insufficiency, } \\
\text { failure) }\end{array}$ & 46 & 17441 & $0.31 \%$ & $0.26 \%$ & - & - & - & - \\
\hline $\begin{array}{l}\text { Urinary/urine-related issues } \\
\text { (incontinence, leak, retention, } \\
\text { urinoma, obstruction, unspecified } \\
\text { urinary complications) }\end{array}$ & 2239 & 45024 & $15.12 \%$ & $11.41 \%$ & 291 & 6563 & $34.11 \%$ & $4.43 \%$ \\
\hline $\begin{array}{l}\text { Other unspecified GU } \\
\text { complications }\end{array}$ & 5137 & 64219 & $34.69 \%$ & $8.00 \%$ & 19 & 4592 & $2.23 \%$ & $0.41 \%$ \\
\hline $\begin{array}{l}\text { Anastomosis-related (stricture, leak, } \\
\text { sclerosis) }\end{array}$ & 1593 & 21728 & $10.76 \%$ & $7.33 \%$ & - & - & - & - \\
\hline $\begin{array}{l}\text { Infection-related (abscess, UTI, } \\
\text { epididymitis, cellulitis, orchitis, } \\
\text { sepsis) }\end{array}$ & 1247 & 61524 & $8.42 \%$ & $2.03 \%$ & 155 & 6563 & $18.17 \%$ & $2.36 \%$ \\
\hline $\begin{array}{l}\text { Cardiovascular/pulmonary } \\
\text { events }^{30,35,36,49,51,66,77,78}\end{array}$ & 1243 & 52778 & $8.39 \%$ & $2.36 \%$ & 5 & 647 & $0.59 \%$ & $0.77 \%$ \\
\hline $\begin{array}{l}\text { Wound-related (dehiscence, disruption, } \\
\text { infection) }\end{array}$ & 1048 & 26952 & $7.08 \%$ & $3.89 \%$ & 68 & 6563 & $7.97 \%$ & $1.04 \%$ \\
\hline
\end{tabular}


Mukkala et al

Unplanned visits after radical prostatectomy

\begin{tabular}{|c|c|c|c|c|c|c|c|c|}
\hline $\begin{array}{l}\text { Bleeding-related (hematoma, } \\
\text { hematuria, hemorrhage, unspecified } \\
\text { GI/GU bleeding) } \\
21,29,30,43,49,51,53,55,66,73,78\end{array}$ & 468 & 52761 & $3.16 \%$ & $0.89 \%$ & 25 & 968 & $2.93 \%$ & $2.58 \%$ \\
\hline Other $^{21,23,30,37,49,51,55,66,77,78}$ & 435 & 40382 & $2.94 \%$ & $1.08 \%$ & 2 & 647 & $0.23 \%$ & $0.31 \%$ \\
\hline $\begin{array}{l}\text { Abdominal/GI (abdominal pains, ileus, } \\
\text { hernia, constipation, jaundice, } \\
\text { lymphoceles, unspecified GI } \\
\text { issues) }\end{array}$ & 368 & 53284 & $2.49 \%$ & $0.69 \%$ & 157 & 6563 & $18.41 \%$ & $2.39 \%$ \\
\hline $\begin{array}{l}\text { Venous thromboembolic events }{ }^{30,35-} \\
37,44,51,55,64,66,78\end{array}$ & 218 & 30647 & $1.47 \%$ & $0.71 \%$ & 131 & 5595 & $15.36 \%$ & $2.34 \%$ \\
\hline Totals & 14807 & 113017 & $100 \%$ & $13.0 \%$ & 853 & 6563 & $100.00 \%$ & $13.0 \%$ \\
\hline
\end{tabular}

ER: emergency room; GI: gastrointestinal; GU: genitourinary; RP: radical prostatectomy; UPV: unplanned visits; UTI: urinary tract infection. 


\begin{tabular}{|c|c|c|c|c|c|}
\hline $\begin{array}{l}\text { Description of } \\
\text { intervention }\end{array}$ & Components of intervention & Efficacy measures & Conclusions & $\mathbf{n}$ & Ref. \\
\hline $\begin{array}{l}\text { Multidisciplinary, } \\
\text { consensus-based } \\
\text { enhanced recovery } \\
\text { after RP in Canada }\end{array}$ & $\begin{aligned} & \text { - } \text { Patient education } \\
& \text { - } \text { Standard medical orders } \\
& \text { - } \text { Customized nursing plan } \\
& \text { for the preoperative visit } \\
& \text { and each day of hospital } \\
& \text { stay (target=2 days) }\end{aligned}$ & $\begin{array}{l}\text { - } 12 \text { ER visit both before } \\
\text { and after pathway, no } \\
\text { change } \\
\text { - No differences in re- } \\
\text { admission rates } \\
\text { between groups either }\end{array}$ & $\begin{array}{l}- \text { Median LoS } \\
\text { significantly reduced } \\
\text { - Complication and re- } \\
\text { admission rates did not } \\
\text { increase } \\
\text { - No direct effect on } \\
\text { UPV }\end{array}$ & 200 & $\begin{array}{l}\text { Abou- } \\
\text { Haider } 2014\end{array}$ \\
\hline $\begin{array}{l}\text { Surgical } \\
\text { modification of } \\
\text { technique for } \\
\text { catheter placement } \\
\text { in RARP }\end{array}$ & $\begin{array}{l}\text { - Suprapubic catheter } \\
\text { placement (SPC) using } \\
\text { trocar with diagrams }\end{array}$ & $\begin{array}{l}\text { - Significant reduction in } \\
\text { catheter-related } \\
\text { problems after RP } \\
(\mathrm{p}=0.03) \\
-6 / 174(3.45 \%) \\
\text { readmitted in urethral } \\
\text { catheter }(\mathrm{UC}) \text { group, } \\
\text { and } 2 / 51(3.92 \%) \text { in } \\
\text { SPC group }(\mathrm{p}=0.45)\end{array}$ & $\begin{array}{l}\text { - SPC is safe and results } \\
\text { in fewer catheter- } \\
\text { related complications } \\
\text { - No direct effect on } \\
\text { UPV }\end{array}$ & 225 & Afzal 2015 \\
\hline $\begin{array}{l}\text { Nurse-led RARP } \\
\text { Care Pathway, } \\
\text { "Robocare" with 10- } \\
\text { steps in Australia }\end{array}$ & $\begin{array}{l}- \text { The 10-step pathway is } \\
\text { shown in Fig. } 1 \\
\text { - A recurrent theme } \\
\text { involves a specialist nurse } \\
\text { that is constantly involved }\end{array}$ & $\begin{array}{l}-29 \text { issues of deviance } \\
\text { from standard care } \\
\text { were detected by phone } \\
\text { clinic }\end{array}$ & $\begin{array}{l}\text { - Study does not have a } \\
\text { control group but does } \\
\text { report a re-admission } \\
\text { rate of } 7.3 \%, \text { which is } \\
\text { lower than the literature } \\
\text { average of } \sim 9 \%\end{array}$ & 124 & Birch 2016 \\
\hline
\end{tabular}




\begin{tabular}{|c|c|c|c|c|c|}
\hline & $\begin{array}{l}\text { with patient care at every } \\
\text { step }\end{array}$ & $\begin{array}{l}\text { - Nine patients required } \\
\text { re-admission and } \\
\text { attention from urologist }\end{array}$ & $\begin{array}{l}\text { - No direct effect of } \\
\text { UPV } \\
\text { - Effective at reducing } \\
\text { re-admission rates }\end{array}$ & & \\
\hline $\begin{array}{l}\text { RN standardized } \\
\text { follow-up and } \\
\text { dedicated post-op } \\
\text { care after RP }\end{array}$ & $\begin{array}{l}\text { - RN was "on-call" to } \\
\text { assess and solve most } \\
\text { patient issues to prevent } \\
\text { re-admission }\end{array}$ & $\begin{array}{l}-131 / 321 \text { (usual care) } \\
\text { vs. } 20 / 115 \text { (pilot } R N) \\
\text { were readmitted after } \\
\text { RP (p=0.02) }\end{array}$ & $\begin{array}{l}\text { - Significantly less re- } \\
\text { admission in the pilot } \\
\text { program } \\
\text { - Has direct effect on } \\
\text { UPV } \\
\text { - Effective at reducing } \\
\text { re-admission and ER } \\
\text { visit rates }\end{array}$ & 321 & $\begin{array}{l}\text { Flannigan } \\
2014\end{array}$ \\
\hline $\begin{array}{l}\text { Home healthcare } \\
\text { after RP in U.S. RN } \\
\text { provided home- } \\
\text { based care after } \\
\text { surgery }\end{array}$ & $\begin{array}{l}\text { - Home healthcare. Nothing } \\
\text { described fully }\end{array}$ & $\begin{array}{l}\text { - Patients with home care } \\
\text { had higher ER visit } \\
(15.5 \% \text { vs } 6.9 \%, \\
\text { p }<0.01) \\
\text { - Similar rates of catheter } \\
\text { duration for }>16 \text { days } \\
(3.6 \% \text { vs } 3.0 \%, p=0.79) \\
\text { and need for catheter } \\
\text { replacement }(1.2 \% \text { vs } \\
2.5 \%, \mathrm{p}=0.46) \\
\text { - Trend toward } \\
\text { decreased re-admission } \\
(0 \% \text { vs } 4.1 \%, p=0.06)\end{array}$ & $\begin{array}{l}- \text { 4\% reduction in re- } \\
\text { admissions but } \\
\text { accompanied with a } \\
\text { doubling of ER visits in } \\
\text { study } \\
- \text { Near-significant trend } \\
\text { towards lowered re- } \\
\text { admission } \\
- \text { Effective at reducing } \\
\text { re-admission rates, and } \\
\text { ineffective at reducing } \\
\text { ER visit rates }\end{array}$ & 647 & Kaye 2018 \\
\hline
\end{tabular}




\begin{tabular}{|c|c|c|c|c|c|}
\hline $\begin{array}{l}\text { A short stay } \\
\text { ambulatory extended } \\
\text { recovery (AXR) } \\
\text { program in U.S. after } \\
\text { MIRP }\end{array}$ & $\begin{array}{l}\text { - } \text { Multidisciplinary team } \\
\text { - Foley catheter care/drain } \\
\text { management and } \\
\text { medication } \\
\text { - Web based interactive } \\
\text { classes, printed materials, } \\
\text { teaching in person and } \\
\text { videos } \\
\text { - Postoperatively a clinical } \\
\text { care pathway was used as } \\
\text { well as nursing-initiated } \\
\text { discharge criteria }\end{array}$ & $\begin{array}{l}\text { - Rates of re-admission } \\
\text { and urgent care visits } \\
\text { were slightly lower } \\
\text { during the ambulatory } \\
\text { extended recovery } \\
\text { phase with no } \\
\text { significant difference } \\
\text { between the groups } \\
\text { - Reduced length of stay } \\
\text { without changing re- } \\
\text { admission or ER visit }\end{array}$ & \begin{tabular}{|l}
- No direct effect on \\
UPV \\
- \\
Slightly lower re- \\
admission and ER visit \\
rates \\
- \\
Ineffective at reducing \\
re-admission and ER \\
visit rates
\end{tabular} & 1571 & $\begin{array}{l}\text { Musser } \\
2015\end{array}$ \\
\hline $\begin{array}{l}\text { Standardized care } \\
\text { pathway for RARP }\end{array}$ & $\begin{array}{l}\text { - Preoperative educational } \\
\text { classes detailing the } \\
\text { procedure, expectations } \\
\text { about recovery and } \\
\text { instructions about pelvic } \\
\text { floor rehabilitation }\end{array}$ & $\begin{array}{l}-75 \% \text { reduction in re- } \\
\text { admission after the } \\
\text { program. No significant } \\
\text { changes in ER visit }\end{array}$ & $\begin{array}{l}\text { Has a significant effect } \\
\text { on re-admission } \\
\text { - Effective at reducing } \\
\text { re-admission rates, } \\
\text { ineffective at reducing } \\
\text { ER visit rates }\end{array}$ & 108 & Turini 2017 \\
\hline $\begin{array}{l}\text { ERAS with specific } \\
\text { clinical course } \\
\text { outlined in LRP }\end{array}$ & $\begin{array}{l}\text { The ERAS program is } \\
\text { described at length in } \\
\text { Table } 1 \text { of the article } \\
\text { - Education; prophylactic } \\
\text { anticoagulation with } \\
\text { heparin; intravenous } \\
\text { anesthesia; preheat fluids } \\
\text { and 1L Ringer's lactate }\end{array}$ & $\begin{array}{l}-2 \text { re-admissions in the } \\
\text { control group and none } \\
\text { in the ERAS group }\end{array}$ & $\begin{array}{l}- \text { Less re-admissions in } \\
\text { ERAS group } \\
- \text { No direct effect on } \\
\text { UPV } \\
-\end{array}$ & 288 & Lin 2019 \\
\hline
\end{tabular}




\begin{tabular}{|c|c|c|c|c|c|}
\hline & $\begin{array}{l}\text { transfusion; encourage } \\
\text { early bedside activity }\end{array}$ & & & & \\
\hline $\begin{array}{l}\text { Fast-track surgery } \\
\text { course after LRP }\end{array}$ & $\begin{array}{l}\text { - Pre-surgery enema x } 2 ; \\
\text { education, scrotal } \\
\text { jockstrap, early movement } \\
\text { exercises } \\
- \text { Details of program } \\
\text { outlined in Table } 2\end{array}$ & $\begin{array}{l}-2 \text { re-admissions in fast- } \\
\text { track group, and } 1 \text { in } \\
\text { the control group }\end{array}$ & $\begin{array}{l}- \text { No direct effect on } \\
\text { UPV }\end{array}$ & 50 & Gralla 2007 \\
\hline $\begin{array}{l}\text { Continued } \\
\text { anticoagulant } \\
\text { therapies during the } \\
\text { perioperative period } \\
\text { after RARP }\end{array}$ & $\begin{array}{l}\text { - Warfarin, DOAC, } \\
\text { clopidogrel, prasugrel } \\
\text { - } \text { Patients with a history of } \\
\text { intervention for CV } \\
\text { disease or stroke were } \\
\text { referred to a specialist for } \\
\text { perioperative continuation } \\
\text { of these drugs }\end{array}$ & $\begin{array}{l}\text { - } 12 / 501 \text { readmitted in } \\
\text { control group and } 2 / 31 \\
\text { readmitted in } \\
\text { anticoagulant group } \\
- \text { Mainly focused on } \\
\text { bleeding outcomes, } \\
\text { cardiovascular risk } \\
\text { stratification, and aims } \\
\text { to reduce DVT burden }\end{array}$ & $\begin{array}{l}\text { - No direct effect on } \\
\text { UPV } \\
\text { - Anticoagulant group } \\
\text { had higher re- } \\
\text { admission rate, } \\
\text { although the N was } \\
\text { small } \\
\text { - }\end{array}$ & 620 & $\begin{array}{l}\text { Kubota } \\
2020\end{array}$ \\
\hline
\end{tabular}

ERAS, fast-track surgery, medical/surgical interventions, and other care pathways assessing re-admissions and/or emergency room visits in radical prostatectomy patients ( $\mathrm{n}=10$ studies). Only primary reports with author-generated data are included in this table. The total RP sample size of these 10 studies was 4154 patients, representing only $\sim 1.0 \%$ of the total RP patients in this review. CV: cardiovascular; DOAC: direct oral anticoagulant; ER: emergency room; ERAS: enhanced recovery after surgery; LoS: length of stay; MIRP: minimally invasive radical prostatectomy; RARP: robot-assisted radical prostatectomy; RN: registered nurse; RP: radical prostatectomy; UPV: unplanned visit. 